\title{
Semi-Crystalline Hydrophobic Polyamidoamines: A New Family of Technological Materials?
}

\author{
Massimo Marcioni ${ }^{1,2}{ }^{,}$Jenny Alongi $^{1}{ }^{1}$, Elisabetta Ranucci ${ }^{1} \oplus$, Mario Malinconico ${ }^{3}$, Paola Laurienzo ${ }^{3}$, \\ Paolo Ferruti ${ }^{1, *(D)}$ and Amedea Manfredi $1, * \mathbb{D}$ \\ 1 Dipartimento di Chimica, Università Degli Studi di Milano, via C. Golgi 19, 20133 Milano, Italy; \\ massimo.marcioni@polito.it (M.M.); jenny.alongi@unimi.it (J.A.); elisabetta.ranucci@unimi.it (E.R.) \\ 2 Dipartimento di Scienza Applicata e Tecnologia, Politecnico di Torino, Alessandria Campus, Viale T. Michel, \\ 15121 Alessandria, Italy \\ 3 Istituto Polimeri, Compositi e Biomateriali (IPCB), Consiglio Nazionale Delle Ricerche, via Campi Flegrei 34 \\ 80078 Pozzuoli, Italy; mario.malinconico@ipcb.cnr.it (M.M.); paola.laurienzo@ipcb.cnr.it (P.L.) \\ * Correspondence: paolo.ferruti@unimi.it (P.F.); amedea.manfredi@unimi.it (A.M.); \\ Tel.: +39-02-50314128 (P.F.); +39-02-50314181 (A.M.)
}

Citation: Marcioni, M.; Alongi, J.;

Ranucci, E.; Malinconico, M.;

Laurienzo, P.; Ferruti, P.; Manfredi, A Semi-Crystalline Hydrophobic Polyamidoamines: A New Family of Technological Materials? Polymers 2021, 13, 1018. https://doi.org/ $10.3390 /$ polym 13071018

Academic Editor: Sylvain Caillol

Received: 2 March 2021

Accepted: 22 March 2021

Published: 25 March 2021

Publisher's Note: MDPI stays neutral with regard to jurisdictional claims in published maps and institutional affiliations.

Copyright: (c) 2021 by the authors. Licensee MDPI, Basel, Switzerland. This article is an open access article distributed under the terms and conditions of the Creative Commons Attribution (CC BY) license (https:// creativecommons.org/licenses/by/ $4.0 /)$.

\begin{abstract}
The hitherto known polyamidoamines (PAAs) are not suitable as structural materials because they are usually water-soluble or swellable in water. This paper deals with the synthesis and characterization of semi-crystalline hydrophobic PAAs (H-PAAs) by combining different bis-secamines with bis-acrylamides obtained from C6-C12 bis-prim-amines. H-PAAs were initially obtained in a solution of benzyl alcohol, a solvent suitable for both monomers and polymers. Their number average molecular weights, $\bar{M}_{n}$, which were determined with ${ }^{1} \mathrm{H}-\mathrm{NMR}$ by evaluating the percentage of their terminal units, varied from 6000 to $>10,000$. The solubility, thermal properties, ignitability and water resistance of H-PAAs were determined. They were soluble in organic solvents, semi-crystalline and thermally stable. The most promising ones were also prepared using a bulk process, which has never been previously reported for PAA synthesis. In the form of films, these H-PAAs were apparently unaffected by water. The films underwent tensile and wettability tests. They showed similar Young moduli (260-263 MPa), whereas the maximum stress and the stress at break depended on the number of methylene groups of the starting bis-acrylamides. Their wettability was somewhat higher than that of common Nylons. Interestingly, none of the H-PAAs considered, either as films or powders, ignited after prolonged exposure to a methane flame.
\end{abstract}

Keywords: linear polyamidoamines; semi-crystalline polyamidoamines; hydrophobic polyamidoamines; flame resistant polymers

\section{Introduction}

Linear polyamidoamines (PAAs) are synthetic polymers obtained from the azaMichael polyaddition of prim-monoamines or bis-sec-amines with bis-acrylamides [1-3]. The reaction is specific since other chemical functions, except thiols and prim- or secphosphine groups, do not participate in it. Nearly all bis-acrylamides, bis-sec-amines and prim-amines available on the market or described in the literature are potential monomers. Consequently, PAAs are a polymer class with high structural versatility. In particular, they can be designed to be biocompatible and degradable [4-6]. All PAAs described so far are highly hydrophilic and in most cases water soluble. Many of them have shown potential as complexing agents of heavy metal ion [7], constituents of sensors [8-10], heparin complexing agents [11-13], drug carriers [14-16], antiviral drugs [17,18] and transfection promoters [19-22]. Proteins graft copolymers have been also described [23].

Cross-linked PAAs are obviously insoluble but swell in water giving hydrogels. Some of these hydrogels proved good scaffolds [24-26] for cell culture and promoted cell adhesion and proliferation both in vitro and in vivo. In the form of tubes, they acted as excellent 
resorbable scaffolds for sciatic nerve regeneration in rats [24]. Undoubtedly, these properties were mediated by their positive charge at the physiological $\mathrm{pH}$ which, however, was too low to elicit cellular toxicity. PAA hydrogels showed poor mechanical properties when swollen in water and were hard and brittle when dry. This has hampered their widespread use as implantable biomaterials. To overcome this problem, several approaches have been investigated, such as the preparation of PAA nanocomposite hydrogels with biocompatible nanosized inorganic fillers, such as montmorillonite [27], or their reinforcement with nanofibrous PLLA (poly(L-lactic acid)) mats previously aminated by plasma treatment with nitrogen [28]. In the latter case, the hydrogels were synthesized by embedding the PLLA mat in the curing solution. The amino groups present on the PLLA fibers participated in the polyaddition reaction and gave rise to matrix-fiber covalent bonds, which ensured the stability of the composite in water. Both approaches were only partially successful. Inorganic nanofillers greatly improved the overall mechanical properties of PAA hydrogels but failed to make them susceptible to being attached to body tissues by stitching. As for the PLLA reinforced composite hydrogels, their preparation was difficult to scale up. So far, no attempts have been made to obtain PAAs inherently endowed with potential as structural materials. This paper aims to fill this gap by reporting the synthesis and properties of a small library of hitherto undescribed semi-crystalline hydrophobic PAAs (H-PAAs) that show promise in this regard.

\section{Materials and Methods}

Materials. Acryloyl chloride (97\%), sodium hydroxide ( $>98 \%), 1,6$-hexanediamine (98\%), 1,8-octanediamine (98\%), 1,10-decanediamine (98\%), 1,12-dodecanediamine ( $\geq 97 \%)$, 2,6-di-tert-butyl-p-cresol ( $\geq 99 \%), N, N^{\prime}$-dimethylethylenediamine (DM2) $(99 \%), N, N^{\prime}$ dimethyl-1,6-hexanediamine (DM6) (97\%), $N, N^{\prime}$-diethylethylenediamine (DE2) (95\%), $N, N^{\prime}$-dibenzylethylenediamine (DB2) (97\%), piperazine (PIP) $(99 \%)$, benzyl alcohol $(\geq 99.8 \%)$, alcohol-free chloroform $(\geq 99.8 \%)$, diethyl ether ( $\geq 99 \%), \mathrm{CDCl}_{3}(99.8 \%)$, $\mathrm{CD}_{3} \mathrm{OD}(99.96 \%), \mathrm{D}_{2} \mathrm{O}(99.9 \%)$ and $\mathrm{CD}_{3} \mathrm{COOD}(99.9 \%)$ were purchased from SigmaAldrich (Milano, Italy) and used as received.

Synthetic procedures. $N, N^{\prime}$-Dodecamethylene-bis-acrylamide (B12). In a $1 \mathrm{~L}$ four-necked round bottom flask, equipped with a thermometer, a mechanical stirrer and two dropping funnels, 1,12-dodecanediamine ( $31.0 \mathrm{~g}, 150.0 \mathrm{mmol})$ was suspended in $\mathrm{CHCl}_{3}(800 \mathrm{~mL})$. Under vigorous stirring, the suspension was cooled to $0 \pm 1^{\circ} \mathrm{C}$ with an acetone/ice bath. Acryloyl chloride $(27.6 \mathrm{~mL}, 329.5 \mathrm{mmol})$ in $\mathrm{CHCl}_{3}(18 \mathrm{~mL})$ and $\mathrm{NaOH}(13.8 \mathrm{~g}, 338.1 \mathrm{mmol})$ in $\mathrm{H}_{2} \mathrm{O}(34 \mathrm{~mL})$ solutions were added dropwise, maintaining the temperature at around $0-2{ }^{\circ} \mathrm{C}$. At the end of the addition, the reaction mixture was allowed to warm up to room temperature and stirred for $24 \mathrm{~h}$. The solid formed was filtered, washed with an acetic acid $/ \mathrm{H}_{2} \mathrm{O} 1: 2 \mathrm{v} / \mathrm{v}$ solution $(270 \mathrm{~mL})$, then with $\mathrm{H}_{2} \mathrm{O}$ until neutral $\mathrm{pH}$. The resulting product was an off-white solid, which was dried under a vacuum to constant weight (Fraction "a"). Yield: $24.9 \mathrm{~g}(54.0 \%)$. An additional crop was recovered by evaporating the mother liquors to dryness, washing the solid residue with $30 \%$ aqueous acetic acid $(40 \mathrm{~mL})$ and then water until neutral $\mathrm{pH}$, and drying to constant weight under a vacuum (Fraction " $\mathrm{b}$ "). Yield: $2.8 \mathrm{~g}$. The ${ }^{1} \mathrm{H}-\mathrm{NMR}$ and FT-IR spectra of the two fractions demonstrated that they were identical.

All other bis-acrylamides were prepared following the same procedure adopted for B12. The amounts of amine used and the yields are reported in Table 1. 
Table 1. Amounts of reagents used in the synthesis of bis-acrylamides ${ }^{(a)}$.

\begin{tabular}{|c|c|c|c|c|}
\hline Code & $\mathbf{N}^{(\mathbf{b})}$ & $\begin{array}{c}\text { Amine } \\
(\mathrm{g})\end{array}$ & $\begin{array}{c}\text { Yield } \\
\text { (g) }\end{array}$ & $\begin{array}{c}\text { Yield } \\
(\%)\end{array}$ \\
\hline B12 & 10 & 31.0 & 27.7 & 60.0 \\
\hline B10 & 8 & 26.4 & 24.0 & 57.0 \\
\hline B8 & 6 & 22.1 & 26.5 & 70.0 \\
\hline B6 & 4 & 17.8 & 20.5 & 61.0 \\
\hline
\end{tabular}

(a) In all cases, the amount of acryloyl chloride was $29.9 \mathrm{~g}(330 \mathrm{mmol}) .{ }^{(\mathrm{b})}$ Number of $\mathrm{CH}_{2}$ groups reported in parentheses; (c) $150 \mathrm{mmol}$.

Synthesis of B6-DM2 by the solution process. $N, N^{\prime}$-Hexamethylene-bis-acrylamide (11.2 g, $50 \mathrm{mmol}), N, N^{\prime}$-dimethylethylenediamine $(4.5 \mathrm{~g}, 50 \mathrm{mmol})$ and benzyl alcohol $(46 \mathrm{~mL})$ were introduced into a $100 \mathrm{~mL}$ screw cap tube, and the mixture was stirred magnetically at $60{ }^{\circ} \mathrm{C}$ for $48 \mathrm{~h}$. The reaction mixture gradually became homogeneous. The solution was finally cooled down to room temperature, precipitated in diethyl ether $(500 \mathrm{~mL})$ under stirring and kept at about $5-8{ }^{\circ} \mathrm{C}$ overnight. The final product was retrieved by filtering and dried under a vacuum as a whitish solid. Yield $13.3 \mathrm{~g}(85 \%)$.

All other polymers were prepared as described for B6-DM2 using the amounts of reagents and solvent reported in Table 2.

Table 2. Amounts of reagents used in the synthesis of H-PAAs by solution ${ }^{(a, b)}$ and bulk processes ${ }^{(b, c)}$.

\begin{tabular}{|c|c|c|c|c|c|c|}
\hline Sample Code ${ }^{(d)}$ & $\begin{array}{l}\text { Bis-Acrylamide } \\
\text { (g) }\end{array}$ & $\begin{array}{c}\text { Bis-Amine } \\
\text { (g) }\end{array}$ & $\begin{array}{c}\text { Benzyl } \\
\text { Alcohol } \\
\text { (mL) }\end{array}$ & $\begin{array}{l}\text { Time } \\
\text { (h) }\end{array}$ & $\begin{array}{c}\text { Yield } \\
{[g,(\%)]}\end{array}$ & $\overline{M_{n}}$ \\
\hline B12-DM2 & 15.4 & 4.5 & 57.0 & 48 & $17.7(89)$ & 9700 \\
\hline B12-DM6 & 15.4 & 7.4 & 65.0 & 48 & $21.3(93)$ & $>10,000$ \\
\hline B12-DE2 & 15.4 & 5.9 & 61.0 & 48 & $18.7(88)$ & 6000 \\
\hline B12-DB2 & 15.4 & 12.4 & 83.0 & 96 & $19.5(70)$ & $<3000$ \\
\hline B12-PIP & 15.4 & 4.4 & 59.0 & 48 & $19.6(99)$ & 6400 \\
\hline B10-DM6 & 14.0 & 7.4 & 61.0 & 48 & $20.4(95)$ & 6000 \\
\hline B8-DM6 & 12.6 & 7.4 & 60.0 & 48 & $18.5(92)$ & 6400 \\
\hline B6-DM2 & 11.2 & 4.5 & 46.0 & 48 & $13.3(85)$ & $>10,000$ \\
\hline B6-DM6 & 11.2 & 7.4 & 55.0 & 48 & $15.5(83)$ & $>10,000$ \\
\hline B6-DE2 & 11.2 & 5.9 & 51.0 & 48 & $11.3(66)$ & 6000 \\
\hline B6-DB2 & 11.2 & 12.4 & 69.0 & 96 & n.d. (e) & $<3000$ \\
\hline B6-PIP & 11.2 & 4.4 & 45.0 & 48 & (98) & $>10,000$ \\
\hline$b$ B12-DM6 ${ }^{(\mathrm{f})}$ & 15.4 & 7.4 & - & 3 & $(\sim 100)$ & 7500 \\
\hline$b \mathrm{~B} 8-\mathrm{DM} 6^{(\mathrm{f})}$ & 12.6 & 7.4 & - & 3 & $(\sim 100)$ & 6400 \\
\hline
\end{tabular}

(a) Temperature $=60{ }^{\circ} \mathrm{C} .{ }^{(b)}$ Monomer amounts: $50 \mathrm{mmol}$. (c) Temperature $=70-140{ }^{\circ} \mathrm{C}$. (d) B12: 1 ,12-dodecamethylene-bisacrylamide; B10: 1,10-decamethylene-bis-acrylamide; B8: 1,8-octamethylene-bis-acrylamide; B6: 1,6-hexamethylene-bis-acrylamide; DM2: $N, N^{\prime}$-dimethylethylenediamine; DM6: $N, N^{\prime}$-dimethyl-1,6-hexanediamine; DE2: $N, N^{\prime}$-diethylethylenediamine; DB2: $N, N^{\prime}-$ dibenzylethylenediamine; PIP: piperazine. ${ }^{(e)}$ n.d.: not determined. ${ }^{(f)}$ Sample obtained by the bulk process.

Synthesis of H-PAAs by the bulk process. B12-DM6. N,N'-dimethyl-1,6-hexanediamine $(15.4 \mathrm{~g}, 50 \mathrm{mmol}), N, N^{\prime}$-dodecamethylene-bis-acrylamide $(7.4 \mathrm{~g}, 32.4 \mathrm{mmol})$ and 2,6-di-tertbutyl-p-cresol $(150 \mathrm{mg})$ were introduced into a hermetically sealed cylindrical glass reactor 
equipped with a thermocouple, a nitrogen inlet and a u-shaped mechanical paddle stirrer. After carefully flushing with nitrogen, the reaction mixture was heated up to $70{ }^{\circ} \mathrm{C}$ while homogenizing under stirring. The temperature was then raised up to $140^{\circ} \mathrm{C}$ within $1 \mathrm{~h}$ and maintained at a constant for further $2 \mathrm{~h}$. After this time, the reacting mixture was allowed to cool down to room temperature. The solidified product was retrieved as a yellowish solid. The yield was quantitative, apart from mechanical losses.

B8-DM6 was prepared as described for B12-DM6, by substituting $N, N^{\prime}$-octamethylenebis-acrylamide (12.4 g) for $N, N^{\prime}$-dodecamethylene-bis-acrylamide and heating up to $150{ }^{\circ} \mathrm{C}$.

Solubility tests. H-PAA solubility was determined in a step-by-step procedure. Polymer samples $(5 \mathrm{mg}$ ) were dispersed in $0.5 \mathrm{~mL}$ of solvent and kept under stirring for $15 \mathrm{~min}$. The samples that did not give a clear solution were heated to the solvent boiling point, and the solubility was ascertained. If insoluble, the solutions were diluted with additional solvent $(0.5 \mathrm{~mL})$ and the procedure was repeated.

Nuclear magnetic resonance. The chemical structure of monomers and polymers was assessed by ${ }^{1} \mathrm{H}-\mathrm{NMR}$ spectroscopy using a Bruker Avance DPX-400 NMR spectrometer (Milano, Italy) operating at $400.13 \mathrm{MHz}$. The spectra of bis-acrylamides were collected in $\mathrm{CD}_{3} \mathrm{OD}$ and those of H-PAAs in $\mathrm{CDCl}_{3}$ at $25^{\circ} \mathrm{C}$.

Thermal properties. Thermogravimetric analyses (TGA) were performed from 35 to $800^{\circ} \mathrm{C}$ in both air and nitrogen on a Mettler-Toledo TGA/DSC 2 Star System instrument (Milano, Italy). Samples (5-10 mg) were placed in alumina crucibles and heated at a

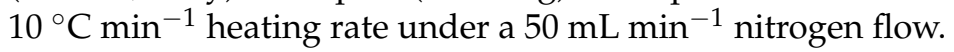

Differential scanning calorimetric (DSC) analyses were performed on a Mettler-Toledo DSC $823^{\text {e }}$ System (Milano, Italy) as follows: samples $(5 \mathrm{mg}$ ) were placed in standard aluminum crucibles and heated or cooled at $5^{\circ} \mathrm{C} \mathrm{min}^{-1}$ under an $80 \mathrm{~mL} \mathrm{~min}^{-1}$ nitrogen flow. The heating program was as follows: 1st step: heating from $25^{\circ} \mathrm{C}$ to $\mathrm{T}_{\mathrm{f}} ; 2$ nd step: $1 \mathrm{~min}$ at $\mathrm{T}_{\mathrm{f}} ; 3$ rd step: cooling from $\mathrm{T}_{\mathrm{x}}$ to $25^{\circ} \mathrm{C}$; 4 th step: $1 \mathrm{~min}$ at $25^{\circ} \mathrm{C} ; 5$ th step: heating from $25^{\circ} \mathrm{C}$ to $\mathrm{T}_{\mathrm{x}} ; 6$ th step: $1 \mathrm{~min}$ at $\mathrm{T}_{\mathrm{f}} ; 7$ th step: cooling from $\mathrm{T}_{\mathrm{x}}$ to $25^{\circ} \mathrm{C}$. $\mathrm{T}_{\mathrm{f}}$ is the maximum temperature typical of each polymer. Result accuracy was $\pm 1{ }^{\circ} \mathrm{C}$ and $\pm 0.01 \mathrm{~J} \mathrm{~g}^{-1}$. Before ea ch set of analyses, the instrument was calibrated with an indium standard. $T_{g}$ values were assessed by a TA Waters instrument Model DSCQ20 (Milano, Italy); samples (5.5 mg) were placed in standard aluminum crucibles and heated or cooled at $10^{\circ} \mathrm{C} \mathrm{min}^{-1}$ under a

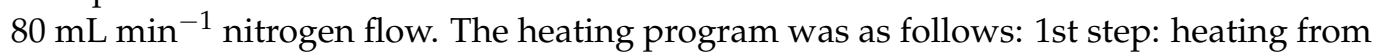
$25^{\circ} \mathrm{C}$ to $\mathrm{T}_{\mathrm{f}} ; 2$ nd step: $1 \mathrm{~min}$ at $\mathrm{T}_{\mathrm{f}} ; 3$ rd step: cooling from $\mathrm{T}_{\mathrm{x}}$ to $-50{ }^{\circ} \mathrm{C} ; 4$ th step: $1 \mathrm{~min}$ at $-50{ }^{\circ} \mathrm{C}$; 5th step: heating from $-50{ }^{\circ} \mathrm{C}$ to $\mathrm{T}_{\mathrm{x}}$.

Ignitability. The ignitability of H-PAAs was assessed by applying a methane flame (20 mm long) directly to the polymer powder $(\sim 500 \mathrm{mg})$ placed on a ceramic-porcelain spoon spatula for $10 \mathrm{~s}$, as already done for other flame retardants [29].

Preliminary evaluation of resistance to handling and to water contact of H-PAA films. Films $0.2 \mathrm{Mm}$ thick were obtained by melting polymer samples $(100 \mathrm{mg})$ on a heating plate in a $5 \mathrm{~cm}^{2}$ frame at a temperature of $20{ }^{\circ} \mathrm{C}$ above their melting point, then pressing with a $1.5 \mathrm{Kg}$ weight for $10 \mathrm{~s}$ at the same temperature and finally cooling to room temperature. One half of the films obtained were incubated in water for $1 \mathrm{~min}$, and the handling resistance was compared with that of the corresponding dry films.

Tensile properties. Tensile stress-strain tests were performed according to the ISO 37-2011 standard. $b$ B12-DM6 and $b$ B8-DM6 films $1 \mathrm{~mm}$ thick were obtained using a compression molding press (Model C, Carver Laboratory Press, Wabash, IN, USA). The samples $(2 \mathrm{~g})$ were first dried at $60^{\circ} \mathrm{C}$ overnight in a vacuum oven, then placed between two pre-heated steel plates at the desired temperature $\left(110^{\circ} \mathrm{C}\right.$ for B12-DM6 and $120^{\circ} \mathrm{C}$ for B8DM6) and finally subjected to 0.5 ton $(191,406 \mathrm{~Pa})$ for $4 \mathrm{~min}$ and then to 0.8 ton $(306,250 \mathrm{~Pa})$ for $1 \mathrm{~min}$. The samples were then cooled to room temperature using circulating water. From this process, films $0.1 \mathrm{~mm}$ thick were obtained. The specimens for the tensile test were obtained using a specific dumbbell (dog-bone like) (total length $70 \mathrm{~mm}$, central zone $25 \mathrm{~mm}$ ). The samples were conditioned for at least $40 \mathrm{~h}$ at $25{ }^{\circ} \mathrm{C}$ and $50 \%$ relative humidity. Film thickness was measured at three random points using a micrometer, and the result 
was expressed as an average value. Tensile strength was measured with an INSTROM 5564 dynamometer (Torino, Italy), using a $1 \mathrm{KN}$ load cell and a $2 \mathrm{~mm} \mathrm{~min}^{-1}$ deformation speed. Several replicate measurements (5-10) were performed on each H-PAA sample.

Wettability. Water contact angle measurements were performed with the contact angle system FTA 1000 B CLASS (First Ten Angstroms St. Johns Innovation Center, Cowley Road, Cambridge CB4 OWS, UK) according to the following protocol: deionized water drops of $30 \pm 2 \mu \mathrm{L}$ in volume were cast on a flat portion of H-PAA film. The shape of the drop was recorded with a high-speed framing camera. The contact angle was assessed by measuring the angle formed between the substrate surface and the tangent drawn from the edge of the drop. Measurements were taken after a static time of $30 \mathrm{~s}$. Contact angles were measured at two points, i.e., near the center and near the edge of the specimens.

\section{Results and Discussion}

As stated in the introduction, the aim of this work was to prepare linear semicrystalline hydrophobic PAAs (H-PAAs) endowed with potential as structural materials in terms of processability and fair mechanical properties. For this purpose, a small library of H-PAAs was prepared from the aza-Michael polyaddition of four $\alpha, \omega$-bis-acrylamides obtained from linear aliphatic C6-C12 bis-prim-amines and several bis-sec-amines, including linear $\alpha, \omega$-aliphatic $\mathrm{N}$-substituted bis-sec-amines; a cyclic bis-sec-amine, namely piperazine; and an $\alpha, \omega$-arylalkyl N-substituted bis-sec-amine, namely $N, N^{\prime}$-dibenzylethylenediamine. Regardless of the aliphatic portion, prim-amines were not considered in this study, as preliminary experiments invariably resulted in amorphous and sticky polymers.

\subsection{Synthesis of Hydrophobic Bis-Acrylamides}

All bis-acrylamides used, i.e., $N, N^{\prime}$-dodecamethylene-bis-acrylamide (B12), $N, N^{\prime}$ decamethylene-bis-acrylamide (B10), $N, N^{\prime}$-octamethylene-bis-acrylamide (B8) and $N, N^{\prime}$ hexamethylene-bis-acrylamide (B6) (Table 1), were synthesized by the Schotten-Baumann reaction [30-32]. A solution of acryloyl chloride in alcohol-free chloroform and an aqueous sodium hydroxide solution were added dropwise with vigorous stirring to a solution or fine suspension of the diamine in chloroform (Scheme 1). The reaction mixture was kept below $5{ }^{\circ} \mathrm{C}$ under stirring throughout the reaction process. The final product, precipitated as a solid and after filtration, was repeatedly washed with dilute acetic acid and then water to remove any traces of unreacted diamine. The chloroform mother liquors were first dried with anhydrous sodium sulphate and then evaporated under a vacuum. A second crop of product was recovered, and the residue was washed with dilute acetic acid and then water. Yields ranged from 60 to $70 \%$.

2<smiles>C=CC(=O)Cl</smiles>

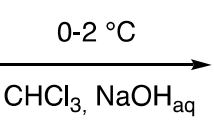

$\mathrm{CHCl}_{3}, \mathrm{NaOH}_{\mathrm{aq}}$<smiles>C=CC(=O)NCC(C)(C)CNC(=O)C=C</smiles>

Scheme 1. Synthesis of the bis-acrylamides used in H-PAA syntheses.

The structures of all bis-acrylamides were confirmed by ${ }^{1} \mathrm{H}-\mathrm{NMR}$ spectroscopy. As an example, the ${ }^{1} \mathrm{H}-\mathrm{NMR}$ spectrum of $\mathrm{B} 12$, performed on $\mathrm{CD}_{3} \mathrm{OD}$, is reported in Figure 1 , while the spectra of all other bis-acrylamides are reported in Figures S1-S3. It may be observed that no separate signals for $\mathrm{N}-\mathrm{H}$ amidic protons can be identified in the ${ }^{1} \mathrm{H}-\mathrm{NMR}$ spectrum of B12 reported in Figure 1. This may be due to different reasons, either rapid proton-deuterium exchange with the relatively acid $\mathrm{O}-\mathrm{D}$ group of $\mathrm{CD}_{3} \mathrm{OD}$ or, as frequently observed, the N-H resonance peak may be very broad and hidden by overlapping with other signals. 


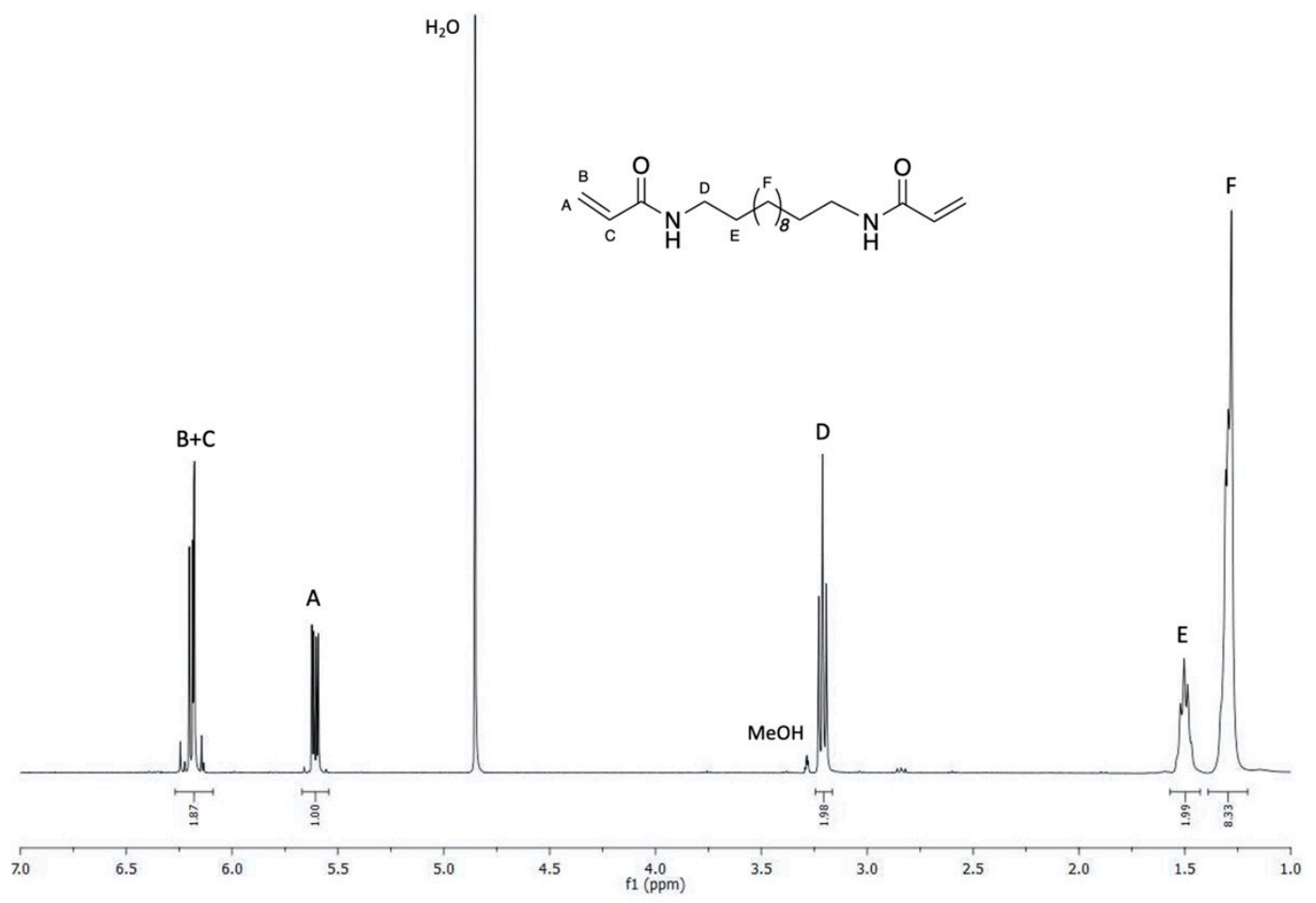

Figure 1. ${ }^{1} \mathrm{H}-\mathrm{NMR}$ spectrum of bis-acrylamide $\mathrm{B} 12$ obtained in $\mathrm{CD}_{3} \mathrm{OD}$ using a $400 \mathrm{MHz}$ Avance Brüker spectrometer. Water assignment was in agreement with the literature $[33,34]$.

\subsection{Synthesis of H-PAAs by the Solution Process}

Twelve not previously described H-PAAs (Table 3) were obtained first by solution polymerization, which is the common synthetic procedure of PAAs reported so far, by combining the bis-acrylamides B6, B8, B10 and B12 (Table 2, Section 2. Materials and Methods) with the five bis-sec-amines reported in Scheme 2.

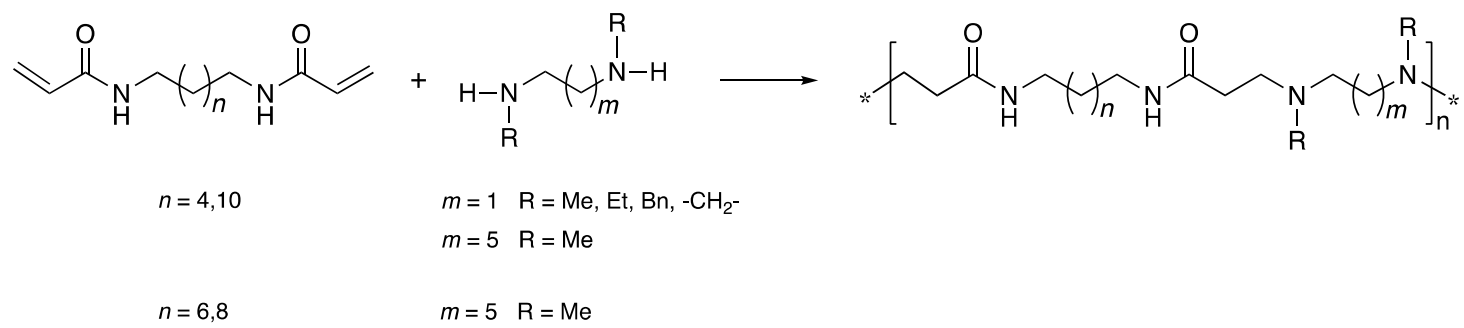

Scheme 2. Synthesis of H-PAAs.

Specifically, B12 and B6 were combined with all five bis-sec-amines, while, for comparison purposes, $\mathrm{B} 10$ and $\mathrm{B} 8$ were only combined with $N, N^{\prime}$-dimethyl-1,6-hexanediamine (DM6). The aza-Michael polyaddition requires solvents with mobile hydrogens, such as water and alcohols, which in principle are poor solvents for hydrophobic polymers. Benzyl alcohol has been shown to be a good reaction medium for both precursor monomers and H-PAAs. All solution polymerization experiments were conducted at $60^{\circ} \mathrm{C}$. The resulting polymers were finally isolated by precipitating with ether. This process required large volumes of solvents, longer reaction times and tedious procedures to remove benzyl alcohol. 
Table 3. Structure of H-PAAs.

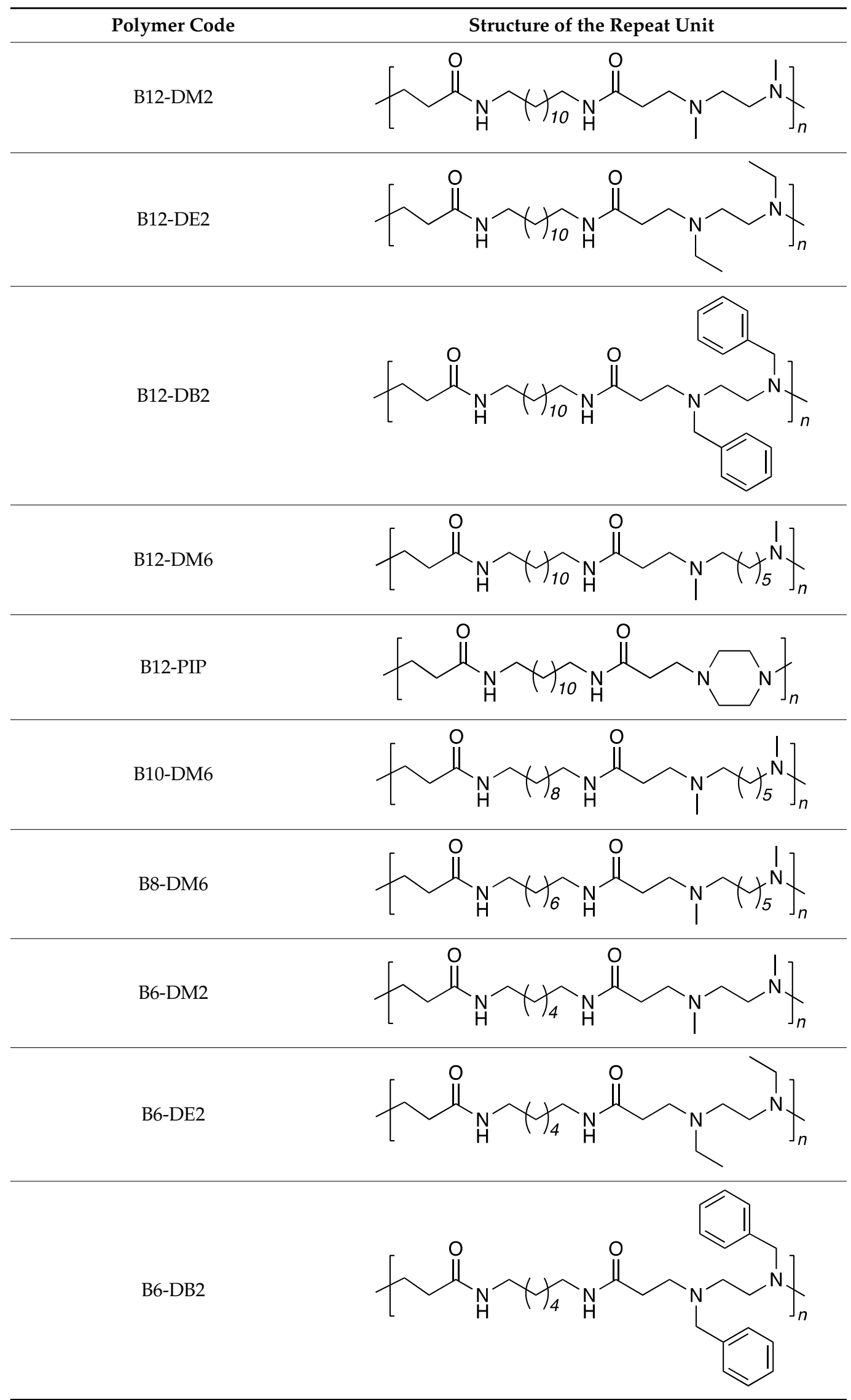


Table 3. Cont.

Polymer Code Structure of the Repeat Unit

All H-PAAs were characterized by ${ }^{1} \mathrm{H}-\mathrm{NMR}$ and FT-IR/ATR spectroscopies. As an example, the ${ }^{1} \mathrm{H}-\mathrm{NMR}$ spectrum of $\mathrm{B} 12-\mathrm{DM} 2$ performed on $\mathrm{CDCl}_{3}$ is reported in Figure 2, while the ${ }^{1} \mathrm{H}-\mathrm{NMR}$ spectra of all other H-PAAs are reported in Figures S4-S14. The FT-IR spectra of all H-PAAs are reported in Figures S17-S27.<smiles>CN(C)CCN(F)CCC(=O)NCCC(C)(C)CCNC(=O)CC(C)(C)C</smiles><smiles>FC1CC1</smiles>

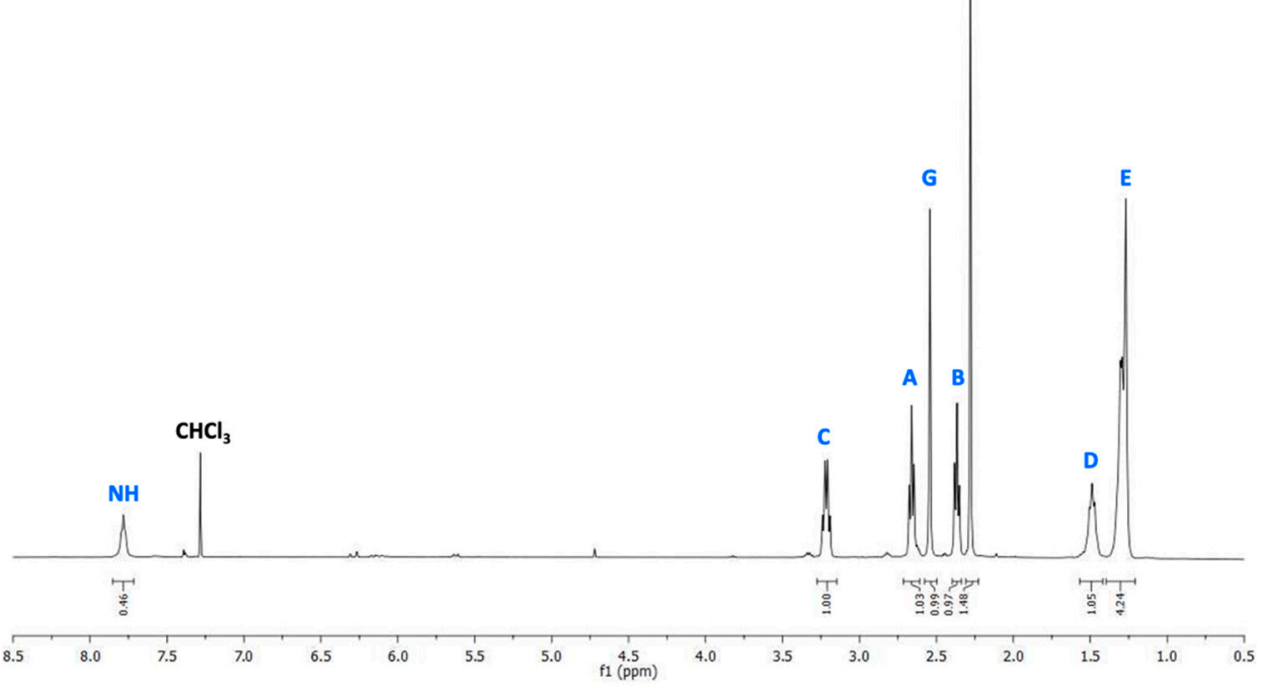

Figure 2. ${ }^{1} \mathrm{H}-\mathrm{NMR}$ spectrum of $\mathrm{H}-\mathrm{PAA}$ B12-DM2 obtained in $\mathrm{CDCl}_{3}$ using a $400 \mathrm{MHz}$ Avance Brüker spectrometer.

All characterizations were in agreement with the proposed structures, apart from the fact that all ${ }^{1} \mathrm{H}-\mathrm{NMR}$ spectra revealed the presence of a benzyl alcohol residue $(1-3 \% w / w)$. This was taken into account in the interpretation of the TGA analyses (see below). The ${ }^{1} \mathrm{H}-\mathrm{NMR}$ spectra allowed us to estimate the number average molecular weights, $\bar{M}_{n}$, of the H-PAAs (see Table 2, Section 2. Materials and Methods) from the ratio between the integrals of the resonance peaks relative to the terminal units and the integrals of the resonance peaks relative to the internal repeating units. Size exclusion chromatography proved inadequate for determining the molecular weights of H-PAAs because they were strongly retained by the stationary phase, regardless of the mobile phases used. It can be seen that the ${ }^{1} \mathrm{H}-\mathrm{NMR}$ spectra of B12-DB2 (Figure S5) and B6-DB2 (Figure S12), both derived from $N, N^{\prime}$-dibenzylethylenediamine, showed significant amounts of residual double bonds, and their $\bar{M}_{n}$ values were less than 3000 . Furthermore, even considering that these polymers were soft and sticky, they were not further considered.

Regarding solubility properties, it can be observed that, apart from the piperazinebased samples B12-PIP and B6-PIP, all H-PAAs had similar solubility properties (Table 4). 
They were completely soluble in chlorinated solvents and boiling alcohols but insoluble in ethers, acetone, dimethyl sulfoxide, water and 30\% aqueous acetic acid. In contrast, both B12-PIP and B6-PIP were insoluble in chlorinated solvents and boiling alcohols but soluble in dilute acetic acid.

Table 4. Solubility of H-PAAs ${ }^{(a)}$.

\begin{tabular}{|c|c|c|c|c|c|c|c|c|c|c|c|c|}
\hline & $\begin{array}{l}\text { B12- } \\
\text { DM2 }\end{array}$ & $\begin{array}{l}\text { B12- } \\
\text { DM6 }\end{array}$ & $\begin{array}{l}\text { B12- } \\
\text { DE2 }\end{array}$ & $\begin{array}{l}\text { B12- } \\
\text { DB2 }\end{array}$ & $\begin{array}{l}\text { B12- } \\
\text { PIP }\end{array}$ & $\begin{array}{l}\text { B10- } \\
\text { DM6 }\end{array}$ & $\begin{array}{l}\text { B8- } \\
\text { DM6 }\end{array}$ & $\begin{array}{l}\text { B6- } \\
\text { DM2 }\end{array}$ & $\begin{array}{l}\text { B6- } \\
\text { DM6 }\end{array}$ & $\begin{array}{l}\text { B6- } \\
\text { DE2 }\end{array}$ & $\begin{array}{c}\text { B6- } \\
\text { DB2 }\end{array}$ & $\begin{array}{l}\text { B6- } \\
\text { PIP }\end{array}$ \\
\hline Methanol & $\mathrm{i}$ & $\mathrm{i}$ & sh & $\mathrm{sh}$ & $\mathrm{i}$ & sh & $\mathrm{sh}$ & $\mathrm{sh}$ & $\mathrm{sh}$ & sh & sh & $\mathrm{i}$ \\
\hline Ethanol & sh & $\mathrm{sh}$ & $\mathrm{sh}$ & $\mathrm{sh}$ & $\mathrm{i}$ & sh & $\mathrm{sh}$ & sh & $\mathrm{sh}$ & sh & $\mathrm{sh}$ & $\mathrm{i}$ \\
\hline Isopropanol & sh & $\mathrm{sh}$ & sh & $\mathrm{sh}$ & $\mathrm{i}$ & sh & sh & $\mathrm{sh}$ & $\mathrm{sh}$ & sh & $\mathrm{sh}$ & $\mathrm{i}$ \\
\hline Butanol & sh & sh & sh & sh & sh & sh & $\mathrm{sh}$ & sh & sh & sh & sh & $\mathrm{i}$ \\
\hline Benzyl alcohol & sh & $\mathrm{s}$ & $\mathrm{s}$ & $\mathrm{s}$ & sh & sh & sh & sh & $\mathrm{s}$ & $\mathrm{S}$ & $\mathrm{s}$ & $\mathrm{sh}$ \\
\hline Acetone & $\mathrm{i}$ & $\mathrm{i}$ & $\mathrm{i}$ & $\mathrm{i}$ & $\mathrm{i}$ & $\mathrm{i}$ & $\mathrm{i}$ & $\mathrm{i}$ & $\mathrm{i}$ & $\mathrm{i}$ & $\mathrm{i}$ & $\mathrm{i}$ \\
\hline $\begin{array}{l}\text { Dimethyl } \\
\text { sulfoxide }\end{array}$ & i & i & i & i & $\mathrm{i}$ & i & i & $\mathrm{i}$ & i & i & i & $\mathrm{i}$ \\
\hline Diisopropyl ether & $\mathrm{i}$ & $\mathrm{i}$ & $\mathrm{i}$ & $\mathrm{i}$ & $\mathrm{i}$ & $\mathrm{i}$ & $\mathrm{i}$ & $\mathrm{i}$ & $\mathrm{i}$ & $\mathrm{i}$ & $\mathrm{i}$ & $\mathrm{i}$ \\
\hline Diethyl ether & $\mathrm{i}$ & $\mathrm{i}$ & $\mathrm{i}$ & $\mathrm{i}$ & $\mathrm{i}$ & $\mathrm{i}$ & $\mathrm{i}$ & $\mathrm{i}$ & $\mathrm{i}$ & $\mathrm{i}$ & $\mathrm{i}$ & $\mathrm{i}$ \\
\hline Chloroform & $\mathrm{s}$ & $\mathrm{s}$ & $\mathrm{s}$ & $\mathrm{s}$ & $\mathrm{i}$ & $\mathrm{s}$ & $\mathrm{s}$ & $\mathrm{s}$ & $\mathrm{s}$ & $\mathrm{s}$ & $\mathrm{s}$ & $\mathrm{i}$ \\
\hline Dichloromethane & $\mathrm{i}$ & $\mathrm{s}$ & $\mathrm{s}$ & $\mathrm{s}$ & $\mathrm{i}$ & $\mathrm{s}$ & $\mathrm{s}$ & $\mathrm{s}$ & $\mathrm{s}$ & $\mathrm{s}$ & $\mathrm{s}$ & $\mathrm{i}$ \\
\hline $\begin{array}{c}\text { Acetic acid/ } \\
\text { water } 1: 2\end{array}$ & $\mathrm{i}$ & $\mathrm{i}$ & $\mathrm{i}$ & $\mathrm{i}$ & $\mathrm{s}$ & $\mathrm{i}$ & $\mathrm{i}$ & $\mathrm{i}$ & $\mathrm{i}$ & $\mathrm{i}$ & $\mathrm{i}$ & $\mathrm{s}$ \\
\hline Water & $\mathrm{i}$ & $\mathrm{i}$ & $\mathrm{i}$ & $\mathrm{i}$ & $\mathrm{i}$ & $\mathrm{i}$ & $\mathrm{i}$ & $\mathrm{i}$ & $\mathrm{i}$ & $\mathrm{i}$ & $\mathrm{i}$ & $\mathrm{i}$ \\
\hline
\end{tabular}

(a) i: insoluble; s: soluble; sh: soluble at boiling point.

\subsection{Synthesis of H-PAAs by the Bulk Process}

A preliminary screening (see below) resulted in the selection of B12-DM6 and B8-DM6 as the best-performing H-PAAs, which were successfully synthesized even following a bulk process. Mixtures of equimolar monomers, added with a radical polymerization inhibitor, were gradually heated under stirring in nitrogen from 70 to $140{ }^{\circ} \mathrm{C}$ and then kept at the latter temperature for $2 \mathrm{~h}$. The reaction mixture was then cooled down and the product used as retrieved. The resulting products, named $b \mathrm{~B} 12-\mathrm{DM} 6$ and $b \mathrm{~B} 8$-DM6, were characterized by ${ }^{1} \mathrm{H}-\mathrm{NMR}$ spectroscopy (Figures S15 and S16). Aside from the obvious absence of solvent impurities, their spectra were nearly identical to those of B12-DM6 and B8-DM6. The $\bar{M}_{n}$ values of $b \mathrm{~B} 12-\mathrm{DM} 6$ and $b \mathrm{~B} 8$-DM6 were of the same order as those of B12-DM6 and B8-DM6. Advantages of the bulk process were that it was much faster than the solution process and avoided the presence of residual solvent. To the best of our knowledge, no examples of PAA synthesis by a bulk polymerization process have been reported so far.

\subsection{Thermal Stability of H-PAAs}

Figure 3 shows the TGA thermograms of H-PAAs conducted on both nitrogen and air in the temperature range of $150-700{ }^{\circ} \mathrm{C}$. Table 5 reports the onset decomposition

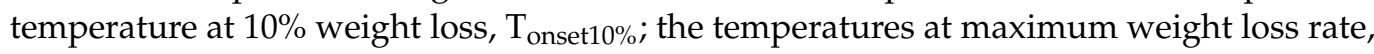
$\mathrm{T}_{\max 1}, \mathrm{~T}_{\max 2}$ and $\mathrm{T}_{\max 3} ;$ and the residual mass fractions measured at 400 and $550{ }^{\circ} \mathrm{C}, \mathrm{RMF}_{400}$ and $\mathrm{RMF}_{550}$. Consistent with what was previously reported for hydrophilic PAAs studied as flame retardants for cotton [29], H-PAAs showed complex multimodal weight-loss curves in both nitrogen and air, deriving from a multistep degradation mechanism. All considered, H-PAAs were characterized by fairly high thermal stability in both atmospheres-higher overall than those of linear water-soluble PAAs - as evidenced by the $\mathrm{T}_{\text {onset } 10 \%}$ and $\mathrm{T}_{\max }$ values. In particular, the $\mathrm{T}_{\text {onset } 10 \%}$ values of all the considered H-PAAs were $>265^{\circ} \mathrm{C}$ in nitrogen and $>266^{\circ} \mathrm{C}$ in air, while the $\mathrm{T}_{\max 1}$ values were $280{ }^{\circ} \mathrm{C}$ in nitrogen and $290^{\circ} \mathrm{C}$ in air. 

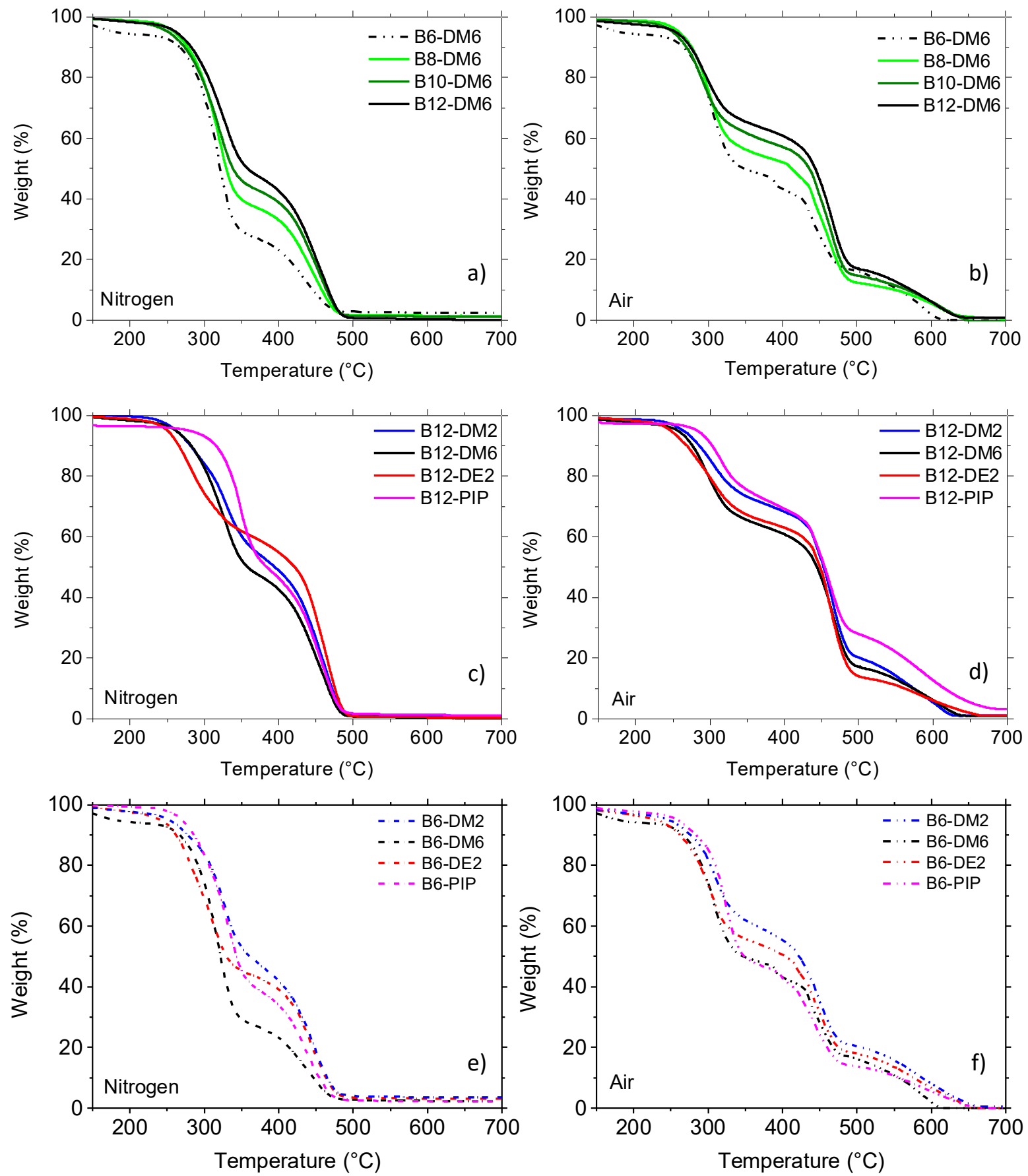

Figure 3. TGA thermograms of H-PAAs: panels $(\mathbf{a}, \mathbf{c}, \mathbf{e})$ in nitrogen; panels $(\mathbf{b}, \mathbf{d}, \mathbf{f})$ in air. 
Table 5. Thermal data collected by thermogravimetric analyses (TGA).

\begin{tabular}{|c|c|c|c|c|c|c|c|c|c|c|}
\hline \multirow[b]{2}{*}{ Polymer } & \multicolumn{4}{|c|}{ Nitrogen } & \multicolumn{6}{|c|}{ Air } \\
\hline & $\mathrm{T}_{\text {onset10\% }}{ }_{\left({ }^{\circ} \mathrm{C}\right)}^{(a)}$ & $\mathrm{T}_{\operatorname{max1}}(\mathrm{b})$ & $\underset{\left({ }^{\circ} \mathrm{C}\right)}{\mathrm{T}_{\max 2}}$ & $\underset{(\%)}{\mathrm{RMF}_{400}(\mathrm{c})}$ & $\begin{array}{c}\mathrm{T}_{\text {onset10\% }} \\
\left({ }^{\circ} \mathrm{C}\right)\end{array}$ & $\begin{array}{l}\mathrm{T}_{\max 1} \\
\left({ }^{\circ} \mathrm{C}\right)\end{array}$ & $\underset{\left({ }^{\circ} \mathrm{C}\right)}{\mathrm{T}_{\max 2}}$ & $\begin{array}{c}\mathrm{T}_{\max 3} \\
\left({ }^{\circ} \mathrm{C}\right)\end{array}$ & $\underset{(\%)}{\mathrm{RMF}_{400}}$ & $\underset{(\%)}{\mathrm{RMF}_{550}}{ }^{(\mathrm{d})}$ \\
\hline B12-DM2 & 281 & 330 & 460 & 49 & 285 & 305 & 462 & 610 & 68 & 14 \\
\hline B12-DE2 & 265 & 280 & 462 & 55 & 268 & 290 & 464 & 575 & 63 & 11 \\
\hline B12-DM6 & 270 & 323 & 459 & 43 & 269 & 299 & 465 & 610 & 61 & 13 \\
\hline B12-PIP & 315 & 347 & 458 & 46 & 297 & 315 & 460 & 585 & 69 & 22 \\
\hline B10-DM6 & 273 & 320 & 456 & 39 & 270 & 292 & 465 & 620 & 57 & 12 \\
\hline B8-DM6 & 278 & 320 & 452 & 33 & 278 & 300 & $442 / 460$ & 610 & 52 & 11 \\
\hline B6-DM2 & 278 & 325 & 445 & 42 & 275 & 310 & 448 & 581 & 55 & 16 \\
\hline B6-DE2 & 265 & 304 & 445 & 39 & 268 & 302 & 447 & 580 & 50 & 12 \\
\hline B6-DM6 & 266 & 316 & 440 & 23 & 266 & 305 & 450 & 587 & 43 & 10 \\
\hline B6-PIP & 286 & 330 & 438 & 34 & 282 & 324 & 446 & 575 & 43 & 11 \\
\hline$b$ B12-DM6 ${ }^{(\mathrm{e})}$ & 271 & 318 & 457 & 41 & 281 & 300 & 464 & 617 & 61 & 13 \\
\hline$b$ B8-DM6 ${ }^{(\mathrm{e})}$ & 279 & 322 & 450 & 34 & 277 & 300 & $441 / 462$ & 612 & 53 & 10 \\
\hline
\end{tabular}

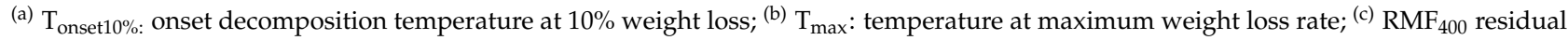
mass fractions measured at $400{ }^{\circ} \mathrm{C}$; (d) $\mathrm{RMF}_{550}$ residual mass fractions measured at $550{ }^{\circ} \mathrm{C}$; (e) sample produced by bulk polymerization process. $\mathrm{RMF}_{550}$ in air is negligible for all samples.

In nitrogen, the $\mathrm{T}_{\text {onset } 10 \%}$ values of $\mathrm{H}-\mathrm{PAAs}$ derived from the same bis-acrylamide (B12 or B6) decreased by varying the structure of bis-sec-amine in the order PIP > DE2 > DM2 > DM6. Furthermore, all H-PAAs, regardless of composition, underwent two main decomposition steps in the ranges of $250-350{ }^{\circ} \mathrm{C}$ and $350-500{ }^{\circ} \mathrm{C}$. The $\mathrm{RMF}_{400}$ values were in all cases relevant. In particular, as regards H-PAAs derived from the same bis-sec-amine, i.e., DM6, and different bis-acrylamides, it was found that the longer the bis-acrylamide hydrocarbon chain, the higher the $\mathrm{RMF}_{400}$ value, i.e., 43, 39, 33 e 23\% for B12-DM6, B10-DM6, B8-DM6 and B6-DM6, respectively (Figure 3a). Regarding the dependence of $\mathrm{RMF}_{400}$ on the structure of the bis-sec-amine moieties in combination with the same bis-acrylamide, no clear correlation was observed (Figure $3 c, e)$. Negligible $(<1 \%)$ RMF was observed for all H-PAAs from $500{ }^{\circ} \mathrm{C}$ and above.

In air, both $\mathrm{T}_{\text {onset } 10 \%}$ and $\mathrm{T}_{\max 2}$ values did not differ significantly from those observed in nitrogen, whereas the $T_{\max 1}$ values were $2-32{ }^{\circ} \mathrm{C}$ lower than in nitrogen, with the sole exception of B12-DE2, whose $\mathrm{T}_{\max 1}$ was $10{ }^{\circ} \mathrm{C}$ higher. Furthermore, in the range of $300-450{ }^{\circ} \mathrm{C}$, all H-PAAs showed a lower weight loss rate in air than in nitrogen and, as a result, the $\mathrm{RMF}_{400}$ values were remarkably higher. This has been attributed to the phenomenon of intumescence, which occurs by heating the air and is recognized as a characteristic of PAAs [29]. In air, as in nitrogen, the $\mathrm{RMF}_{400}$ values of H-PAA derived from DM6 increased with the increase in the bis-acrylamide hydrocarbon chain length, i.e., they were 61, 57, 52 and 43\% for B12-DM6, B10-DM6, B8-DM6 and B6-DM6 (Figure 3b). No clear correlation between $\mathrm{RMF}_{400}$ values and the structure of the amine moiety was found (Figure 3d,f). In addition to the decomposition steps observed in nitrogen in the temperature ranges of $250-350{ }^{\circ} \mathrm{C}$ and $350-500{ }^{\circ} \mathrm{C}$, a third decomposition step was observed in the range of $500-650{ }^{\circ} \mathrm{C} . \mathrm{RMF}_{550}$ values were between 10 and $13 \%$, while in nitrogen they were less than $1 \%$, and almost vanished above $600-650^{\circ} \mathrm{C}$.

The thermal data of $b \mathrm{~B} 12-\mathrm{DM} 6$ and $b \mathrm{~B} 8$-DM 6 in air and nitrogen, prepared by the bulk process, were almost superimposable to those of samples obtained from the solution process (Figure S30 for B12-DM6).

Comparing the thermal data of H-PAAs with those of common commercial polymers, it was observed that the $\mathrm{T}_{\text {onset } 10 \%}$ and $\mathrm{T}_{\max }$ of H-PAAs did not differ significantly when switching from air to nitrogen, while those of PP [35] and HDPE [35,36] were about $50-150{ }^{\circ} \mathrm{C}$ lower in air than in nitrogen. Furthermore, above $\mathrm{T}_{\max }$, the RMF of PE and PP in the air drops to a negligible amount. In contrast, in air H-PAAs showed a substantial RMF (15-30\%) up to $500-650{ }^{\circ} \mathrm{C}$, where a third $\mathrm{T}_{\max }$ occurred. It may be observed that 
the $\mathrm{T}_{\text {onset } 10 \%}$ values of polybutylene terephthalate (PBT) [37], polyethylene terephthalate (PET) $[38,39]$ and nylon 6 (PA6) $[40,41]$ were higher than those of H-PAAs. Furthermore, they showed a single $T_{\max }$ value, while H-PAAs showed two $T_{\max }$ values, the first lower than- and the second, comparable to those of PBT, PET and PA6. Furthermore, the RMF values of PBT, PET and PA6 above $\mathrm{T}_{\max }$ are significant $\left(18 \%\right.$ at $480{ }^{\circ} \mathrm{C}$ for PET [38] $8 \%$ at $500{ }^{\circ} \mathrm{C}$ for PA6 [40]) but invariably lower than those of H-PAAs, which become negligible only above $600-650^{\circ} \mathrm{C}$.

Figure 4 shows the DSC thermograms of H-PAAs relating to the 2nd heating cycle at $10^{\circ} \mathrm{C} \mathrm{min}^{-1}$, and Figure S31 shows those pertaining to the cooling cycle. The onset melting temperatures, $\mathrm{T}_{\text {onset }}$; the melting and crystallization temperatures, $\mathrm{T}_{\mathrm{m}}$ and $\mathrm{T}_{\mathrm{c}}$; the melting and crystallization enthalpies, $\Delta \mathrm{H}_{\mathrm{m}}$ and $\Delta \mathrm{H}_{\mathrm{c}}$; and the glass transition temperatures, $\mathrm{T}_{\mathrm{g}}$, are listed in Table 6. All H-PAAs, with the exception of B6-DE2, were semi-crystalline and provided evidence of melting (Figure 4c) and crystallization (Figure S31c). In particular, samples B12-PIP, B6-PIP, B12-DM2 and B6-DM6 showed bimodal melting traces. Quite surprisingly, B10-DM6 showed evidence of melting (Figure 4e) but not of extensive recrystallization (Figure S31e). Furthermore, both PIP-based samples exhibited particularly high $\mathrm{T}_{\mathrm{m} 2}$ values: $196 / 216$ and $223 / 236^{\circ} \mathrm{C}$ for B12-PIP and B6-PIP, respectively (Table 6 and Figure $4 b, d)$.
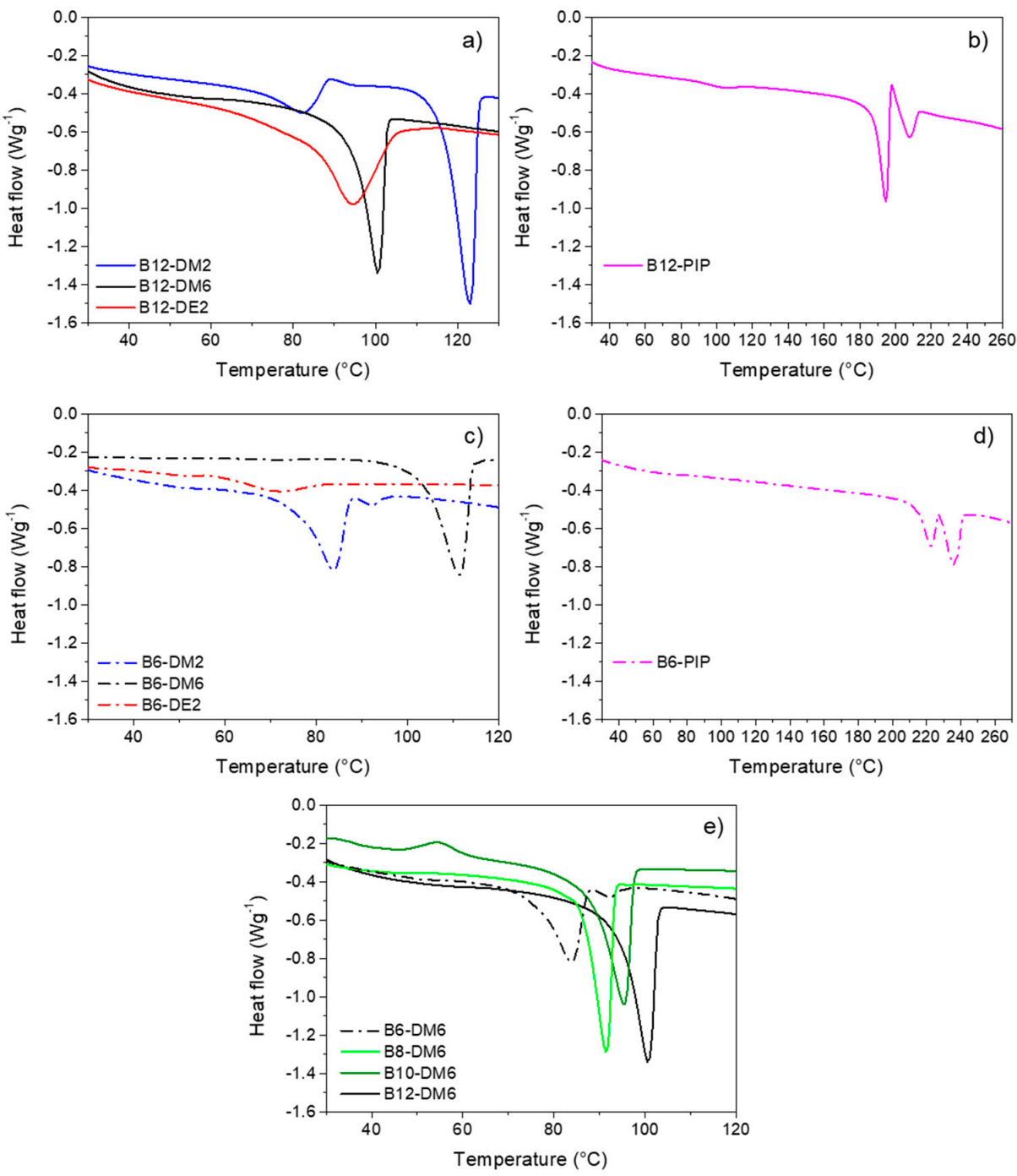

Figure 4. Differential scanning calorimetric (DSC) thermograms pertaining to the 2 nd heating cycle at $10{ }^{\circ} \mathrm{C} \mathrm{min}^{-1}$ of: (a) B12-DM2, B12-DM6 and B12-DE2; (b) B12-PIP; (c) B6-DM2, B6-DM6 and B6-DE2; (d) B6-PIP; (e) B6-DM6, B8-DM6, B10-DM6 and B12-DM6. 
Table 6. Thermal data collected by DSC.

\begin{tabular}{|c|c|c|c|c|c|c|c|c|c|c|}
\hline \multirow[b]{2}{*}{ Polymer } & \multicolumn{3}{|c|}{ 1st Heating Cycle } & \multicolumn{3}{|c|}{ Cooling Cycle } & \multicolumn{3}{|c|}{ 2nd Heating Cycle } & \multirow[b]{2}{*}{$\begin{array}{l}\mathrm{T}_{\mathrm{g}}{ }^{(\mathbf{l})} \\
\left({ }^{\circ} \mathrm{C}\right)\end{array}$} \\
\hline & $\begin{array}{c}\mathrm{T}_{\text {onset,m1 }}{ }^{(a)} \\
\left({ }^{\circ} \mathrm{C}\right)\end{array}$ & $\begin{array}{c}\mathrm{T}_{\mathrm{m} 1}(\mathrm{~b}) \\
\left({ }^{\circ} \mathrm{C}\right)\end{array}$ & $\underset{\left(\mathrm{Jg}^{-1}\right)}{\Delta \mathrm{H}_{\mathrm{m}}{ }^{(\mathrm{c})}}$ & $\begin{array}{c}\mathrm{T}_{\text {onset,cr }} \text { (d) } \\
\left({ }^{\circ} \mathrm{C}\right)\end{array}$ & $\begin{array}{l}\mathrm{T}_{\mathrm{cr}}(\mathrm{e}) \\
\left({ }^{\circ} \mathrm{C}\right)\end{array}$ & $\begin{array}{c}\Delta \mathbf{H}_{\mathrm{cr}}{ }^{(\mathrm{f})} \\
\left(\mathrm{Jg}^{-1)}\right.\end{array}$ & $\begin{array}{c}\mathrm{T}_{\text {onset,m2 }}(\mathrm{g}) \\
\left({ }^{\circ} \mathrm{C}\right)\end{array}$ & $\begin{array}{c}\mathrm{T}_{\mathrm{m} 2}(\mathrm{~h}) \\
\left({ }^{\circ} \mathrm{C}\right)\end{array}$ & $\underset{\left(\mathrm{Jg}^{-1}\right)}{\Delta \mathrm{H}_{\mathrm{m}}{ }^{(\mathrm{i})}}$ & \\
\hline B12-DM2 & 70 & 83 & -23.4 & 97 & 91 & 49.3 & 116 & 123 & -76.6 & -10 \\
\hline B12-DM6 & - & - & - & 71 & 61 & 58.6 & 95 & 100 & -63.3 & -19 \\
\hline B12-DE2 & - & - & - & 80 & 74 & 82.3 & 83 & 95 & -95.5 & n.d. $(\mathrm{m})$ \\
\hline B12-PIP & 188 & 195 & -51.3 & 181 & 179 & 48.5 & 198 & $196 / 216$ & -18.3 & +32 \\
\hline B10-DM6 & - & - & - & 53 & 44 & 3.2 & 88 & 95 & -62.0 & -19 \\
\hline B8-DM6 & - & - & & 53 & 46 & 54.4 & 86 & 90 & -57.1 & -20 \\
\hline B6-DM2 & - & - & - & 78 & 72 & 53.6 & 103 & 111 & -54.5 & -13 \\
\hline B6-DM6 & 76 & 84 & -37.1 & 55 & 50 & 48.1 & 89 & 84 & -51.1 & -23 \\
\hline B6-DE2 & - & - & - & - & - & - & - & - & - & - \\
\hline B6-PIP & 216 & 222 & -13.2 & 205 & 200 & 53.4 & 228 & $223 / 236$ & -24.2 & +55 \\
\hline$b \mathrm{~B} 12-\mathrm{DM} 6$ & - & - & - & 68 & 62 & 34.6 & 98 & 105 & -72.2 & -10 \\
\hline$b$ B8-DM6 & - & - & - & 63 & 57 & 53.0 & 93 & 100 & -50.8 & -16 \\
\hline
\end{tabular}

1st Heating cycle: (a) $\mathrm{T}_{\text {onset, } \mathrm{m} 1}$ : the onset temperature, the intersection of the tangent of the melting peak with the extrapolated baseline; (b) $\mathrm{T}_{\mathrm{m} 1}$ : melting temperature; (c) $\Delta \mathrm{H}_{\mathrm{m} 1}$ : enthalpy of melting. Cooling cycle: ${ }^{(\mathrm{d})} \mathrm{T}_{\mathrm{onset}}$, cr : the onset temperature defined as the intersection of the tangent of the crystallization peak with the extrapolated baseline; ${ }^{(\mathrm{e})} \mathrm{T}_{\mathrm{cr}}$ : crystallization temperature; ${ }^{(\mathrm{f})} \Delta \mathrm{H}_{\mathrm{cr}}$ : enthalpy of crystallization.

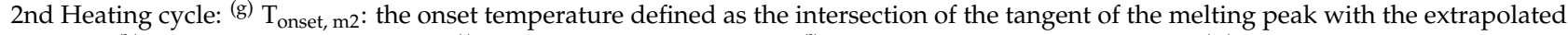
baseline; ${ }^{(h)} \mathrm{T}_{\mathrm{m} 2}$ : melting temperature; ${ }^{(\mathrm{i})} \Delta \mathrm{H}_{\mathrm{m} 2}$ : enthalpy of melting; ${ }^{(1)} \mathrm{T}_{\mathrm{g}}$ : glass transition temperature; ${ }^{(\mathrm{m})}$ n.d.: not detected.

H-PAAs derived from both B12 (Figure 4a) and B6 (Figure 4c) showed the same ranking of $T_{m}$ values based on the structure of the amine moiety: PIP > DM2 > DM6 > DE2. It should be remembered that B6-DE2 did not melt nor crystallize. Within the DM6 series, $\mathrm{T}_{\mathrm{m} 2}$ values $\left(100,95,90\right.$ and $84{ }^{\circ} \mathrm{C}$ for B12-DM6, B10-DM6, B8-DM6 e B6-DM6, respectively) were clearly dependent on the bis-acrylamide chain length and decreased by decreasing the number of the bis-acrylamide carbon atoms (Figure $4 \mathrm{e}$ ). The $\Delta \mathrm{H}_{\mathrm{m} 2}$ values also decreased by decreasing the number of carbon atoms in the series $\left(63.3,62.0,57.1\right.$ and $51.1 \mathrm{Jg}^{-1}$ for B12-DM6, B10-DM6, B8-DM6 e B6-DM6, respectively). The differences between the thermal data of $\mathrm{B} 12-\mathrm{DM} 6$ and $b \mathrm{~B} 12-\mathrm{DM} 6$, and between those of B8-DM6 and $b \mathrm{~B} 8$-DM6, were not relevant (Figure S32).

Regarding the cooling cycle, both B12-PIP and B6-PIP showed the highest crystallization temperatures, $\mathrm{T}_{\mathrm{C}}$, of the B12- and B6-series $\left(179{ }^{\circ} \mathrm{C}\right.$ for B12-PIP and $200{ }^{\circ} \mathrm{C}$ for B6-PIP), as already observed for $\mathrm{T}_{\mathrm{m} 2}$ values. Furthermore, within the DM6-series, $\mathrm{T}_{\mathrm{c}}$ showed almost the same trend observed for $\mathrm{T}_{\mathrm{m} 2}$, with the exception of B12-DM6 and B12-DE2. The significant increase in the melting enthalpy of B12-DM6 compared with B8-DM6 can be explained by the greater mobility of the B12 chains that can arrange in larger crystalline domains.

The glass transition temperatures, $\mathrm{T}_{\mathrm{g}}$, of H-PAAs were between -10 and $-23{ }^{\circ} \mathrm{C}$, except for B12-PIP and B6-PIP, whose $\mathrm{T}_{\mathrm{g}}$ values were $32{ }^{\circ} \mathrm{C}$ and $55^{\circ} \mathrm{C}$, respectively. Remarkably, the $\mathrm{T}_{\mathrm{g}}$ of B12-DE2 was not detectable. Within the DM6 series, the $\mathrm{T}_{\mathrm{g}}$ values decreased slightly as the bis-acrylamide chain length increased $\left(-19,-19,-20\right.$, and $-23{ }^{\circ} \mathrm{C}$ for B12-DM6, B10-DM6, B8-DM6 and B6-DM6, respectively). The $\mathrm{T}_{\mathrm{g}}$ values of $b \mathrm{~B} 12-\mathrm{DM} 6$ and $b \mathrm{~B} 8$-DM6 were slightly higher than those of the corresponding samples obtained in solution. This is likely due to the presence, in the latter, of the residual impurities of benzyl alcohol.

\subsection{Preliminary Evaluation of the Effect of Water Contact on the Macroscopic Properties of H-PAA Films}

H-PAA films with an average thickness of $0.2 \mathrm{~mm}$ were prepared by compression molding. The specimens were visually evaluated for their flexibility and ability to withstand small stresses and then placed in contact with water to ascertain the effect of water on the observed properties (see Table 7). These tests provided the criteria for selecting B12-DM6 and B8-DM6 as the best H-PAA samples for studying the feasibility of the bulk polymerization process and further evaluating the wettability and tensile properties of the resulting $b \mathrm{~B} 12-\mathrm{DM} 6$ and $b \mathrm{~B} 8$-DM6 samples. 
Table 7. Preliminary evaluation of the effect of water contact on the macroscopic properties of H-PAA films $\left(20^{\circ} \mathrm{C}\right)$.

\begin{tabular}{|c|c|c|c|}
\hline Polymer & $\begin{array}{l}\text { Apparent } \\
\text { Flexibility }\end{array}$ & Resistance to Handling & $\begin{array}{c}\text { Resistance after Contact } \\
\text { with Water }\end{array}$ \\
\hline B12-DM2 & + & + & - \\
\hline B12-DM6 & + & + & + \\
\hline B12-DE2 & + & + & - \\
\hline B12-PIP & - & - & - \\
\hline B10-DM6 & + & + & + \\
\hline B8-DM6 & + & + & + \\
\hline B6-DM2 & + & + & - \\
\hline B6- DM6 & + & + & + \\
\hline B6-DE2 & + & + & - \\
\hline B6-PIP & - & - & + \\
\hline
\end{tabular}

\subsection{Ignitability Tests}

The ignitability of H-PAAs was assessed by direct flame impingement for $10 \mathrm{~s}$ on powdered samples (snapshots reported in Figure 5). The samples did not ignite when the flame was applied and exhibited minimal weight loss $(<5 \%)$. Their surface melted and decomposed, yellowing slightly, and produced carbonaceous crusts that protected the underlying powders, which remained white and apparently intact. This behavior testified the tendency of H-PAAs to intumesce upon heating and was in line with previous ignitability data obtained with hydrophilic PAAs [29,42]. It also demonstrated that inserting a large hydrophobic moiety in their repeating unit did not significantly affect their flame resistance. The inherent intumescent behavior of PAAs is a rarely seen feature in polymeric flame retardants. Similar behavior, in fact, has been observed only in DNA and in some proteins for which, however, industrial exploitation for this purpose is almost inconceivable [43-45].
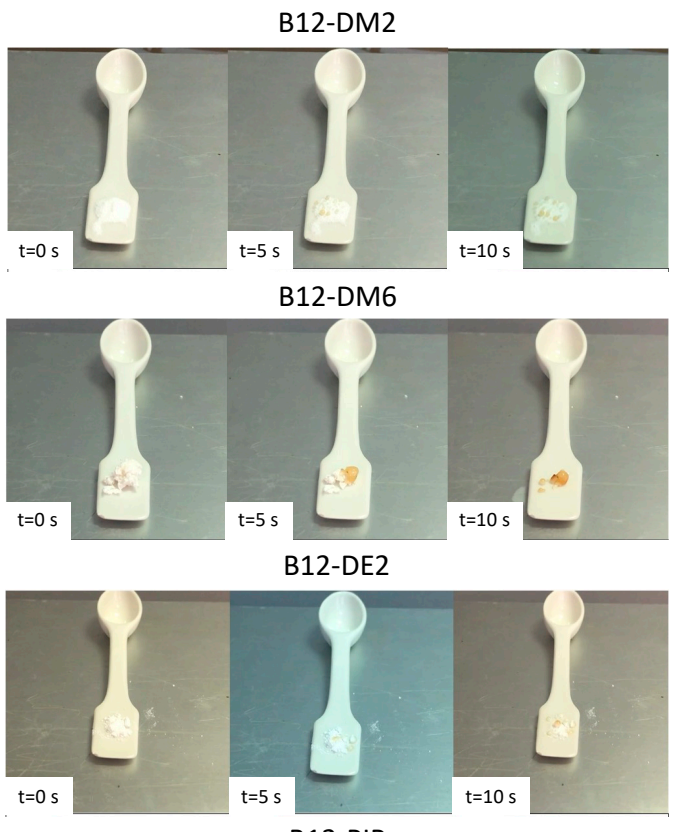

B12-PIP

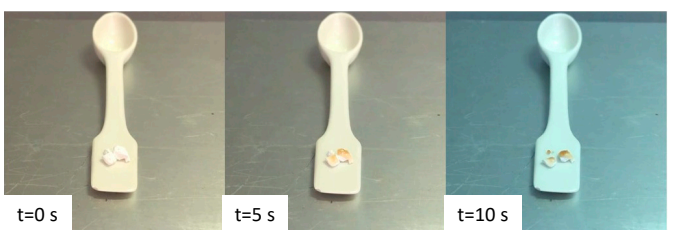

Figure 5. Snapshot of the results of ignitability tests carried out on H-PAA powders. 


\subsection{Preliminary Evaluation of Tensile Properties of bB12-DM6 and bB8-DM6}

The tensile properties of $b \mathrm{~B} 12$-DM6 and $b \mathrm{~B} 8$-DM6 were investigated on $0.1 \mathrm{~mm}$ thick dog bone shaped specimens following the ISO 37-2011 standard. The results are shown in Figure 6 and Table 8.

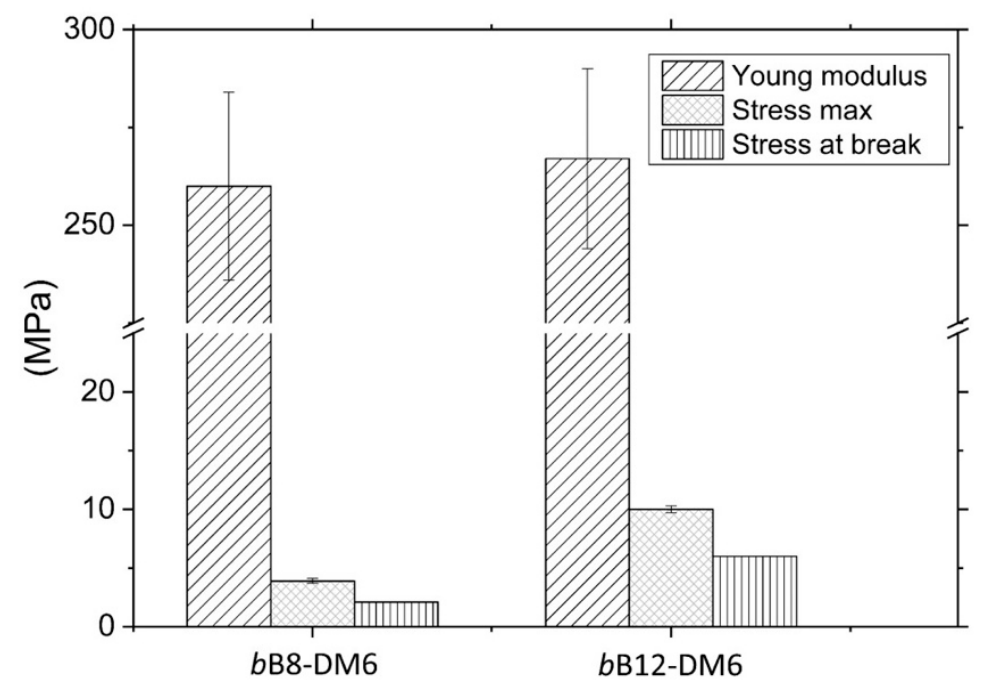

Figure 6. Graphical representation of $b \mathrm{~B} 12-\mathrm{DM} 6$ and $b \mathrm{~B} 8$-DM6 tensile properties.

Table 8. Tensile data of $b \mathrm{~B} 8$-DM6 and $b \mathrm{~B} 12-\mathrm{DM} 6$.

\begin{tabular}{cccccc}
\hline Sample & $\begin{array}{c}\text { Thickness } \\
(\mathbf{m m})\end{array}$ & $\begin{array}{c}\text { Young } \\
\text { Modulus } \\
\text { (MPa) }\end{array}$ & $\begin{array}{c}\text { Stress Max } \\
\text { (MPa) }\end{array}$ & $\begin{array}{c}\text { Stress at } \\
\text { Break (MPa) }\end{array}$ & $\begin{array}{c}\text { Strain at } \\
\text { Break (\%) }\end{array}$ \\
\hline$b$ B8-DM6 & $0.10 \pm 0.02$ & $260 \pm 24$ & $3.9 \pm 0.2$ & $2.1 \pm 0.5$ & $1.7 \pm 0.2$ \\
\hline$b$ B12-DM6 & $0.12 \pm 0.02$ & $267 \pm 23$ & $10.0 \pm 0.3$ & $5.9 \pm 1.9$ & $6.9 \pm 0.3$ \\
\hline
\end{tabular}

(a) Maximal value of the stress-strain curve.

It is evident that $b \mathrm{~B} 12-\mathrm{DM} 6$ and $b \mathrm{~B} 8-\mathrm{DM} 6$ have a similar Young's modulus. It should be noted that they have similar molecular weights, despite their degrees of polymerization being somewhat different. Furthermore, the samples did not undergo a visible yield before failure. It can also be observed that all tensile data, i.e., the strain at break, the stress at break and the maximum stress of the two samples, differed significantly. Not surprisingly, these values increased from $b \mathrm{~B} 8$-DM6 to $b \mathrm{~B} 12$-DM6, i.e., by increasing the length of the bisacrylamide hydrocarbon chain. The greater maximum stress value of B12-DM6, compared with B8-DM6, is linked to the greater crystallinity of the first polymer, as also highlighted by the thermal data.

\subsection{Wettability}

The wettability of $b \mathrm{~B} 12-\mathrm{DM} 6$ and $b \mathrm{~B} 8$-DM6 was assessed by measuring the contact angle with water using the sessile drop method. Contact angles were measured both near the center and at the edge of the samples. Results are reported in Figure 7 and Table 9. It is evident that the wettability of $b \mathrm{~B} 12-\mathrm{DM} 6$ was significantly lower than that of $b \mathrm{~B} 8$-DM6, as expected. In fact, the proportion between the hydrophobic chains and the hydrophilic amide and amine groups of the former is higher. 


\section{bB12-DM6}
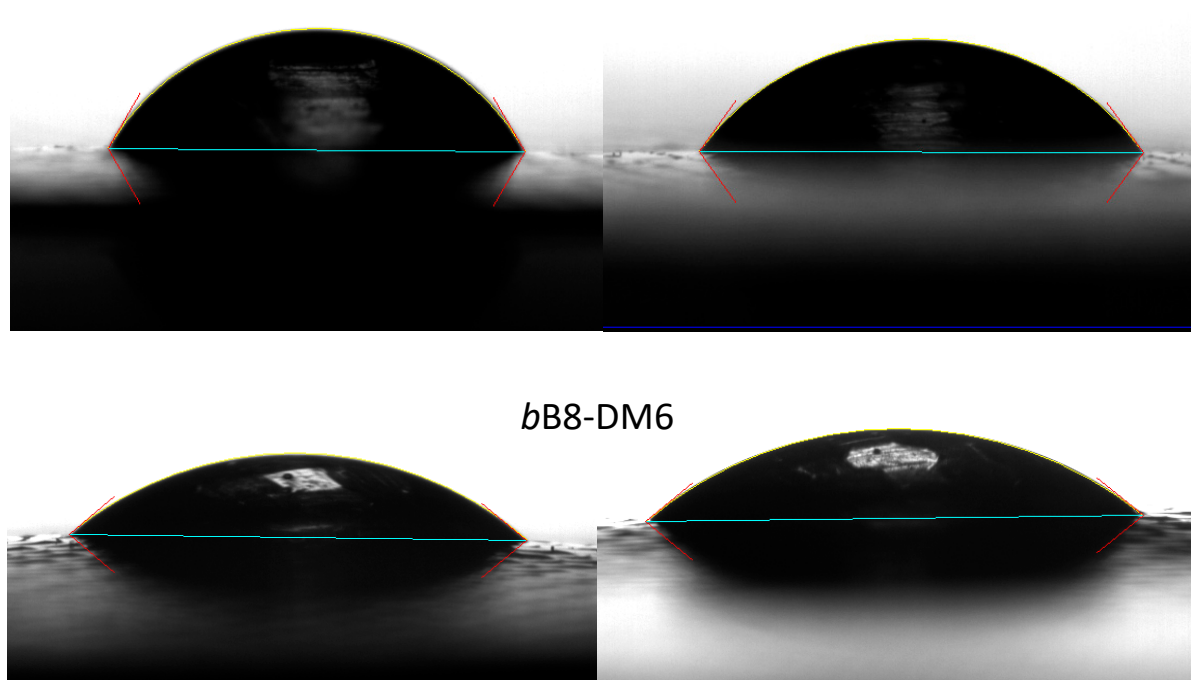

Figure 7. Contact angle measurements on $b \mathrm{~B} 12-\mathrm{DM} 6$ (upper row) and $b \mathrm{~B} 8$-DM6 (lower row) films: contact point close to the border (left panels); contact point near the center of the specimen (right panels).

Table 9. Wettability of H-PAAs.

\begin{tabular}{ccccccc}
\hline $\begin{array}{c}\text { Polymer } \\
\text { Sample }\end{array}$ & Place & $\begin{array}{c}\text { Contact } \\
\text { Angle } \\
(\mathbf{d e g})\end{array}$ & $\begin{array}{c}\text { Wetting } \\
\text { Tension } \\
(\mathbf{d y} / \mathbf{c m})\end{array}$ & Base $(\mathbf{m m})$ & $\begin{array}{c}\text { Base Area } \\
\left(\mathbf{m m}^{\mathbf{2}}\right)\end{array}$ & $\begin{array}{c}\text { Sessile } \\
\text { Volume } \\
(\boldsymbol{\mu} \mathbf{L})\end{array}$ \\
\hline$b$ B8-DM6 & Border & 39.9 & 56.0 & 7.6 & 44.8 & 32.0 \\
\hline$b$ B8-DM6 & Center & 40.3 & 55.7 & 7.3 & 40.9 & 28.4 \\
\hline$b$ B12-DM6 & Border & 60.5 & 35.9 & 6.1 & 28.8 & 28.3 \\
\hline$b$ B12-DM6 & Center & 54.2 & 42.7 & 6.7 & 33.9 & 31.0 \\
\hline
\end{tabular}

\section{Conclusions}

The aim of this work was to prepare linear hydrophobic semi-crystalline PAAs with fair physical and mechanical properties using hydrophobic bis-acrylamides and bis-secamines as monomers. A small library of twelve linear H-PAAs was synthesized and characterized. A preliminary investigation into the relationship between structure and relevant physical properties allowed us to select a limited number of samples, investigated with regards to wettability and tensile properties.

H-PAAs were prepared by both solution and bulk processes. Initially, all the samples were prepared by a solution process, by analogy with the linear PAAs described so far in the literature, employing benzyl alcohol as the solvent. The samples selected for wettability and tensile tests, i.e., $b$ B12-DM6 and $b$ B8-DM6, were also prepared by a bulk process, never previously described for the synthesis of PAAs. The bulk process was carried out under a nitrogen atmosphere at a temperature well above the melting points of both the monomers and the resulting polymers and in the presence of a radical inhibitor. This process proved more effective as it led to samples with no need for further purification. The number of the average molecular weights of $b$ B12-DM6 and $b$ B8-DM6 did not differ significantly from those of the corresponding samples obtained from the solution process.

The H-PAAs obtained by the solution process were first screened for the molecular weight obtainable and, subsequently, physical properties including thermal properties, filmability, flammability, apparent strength and water resistance. Samples B12-DB2 and B6-DB2 were discarded due to their low molecular weight, as revealed by the significant presence of residual double bonds in their ${ }^{1} \mathrm{H}-\mathrm{NMR}$ spectra. Furthermore, they were sticky and apparently unable to crystallize. All remaining H-PAAs were semi-crystalline, with the sole exception of B6-DE2. The melting temperatures of the H-PAAs derived from the same 
amine, namely DM6, clearly increased by increasing the length of the bis-acrylamide moiety. Those of the H-PAAs derived from the same bis-acrylamide and different bis-amines also depended on the structure of the amine substituent. The order for H-PAAs-derived B12 and B6 was PIP >> DM2 > DM6 > DE2. B6-DE2 did not crystallize.

Overall, the thermal stability of H-PAAs was considerably higher, in terms of $\mathrm{T}_{\text {onset } 10 \%}$ and $\mathrm{T}_{\max }$, than those of the hydrophilic PAAs studied so far [29]. Furthermore, as hydrophilic PAAs, they were significantly more stable in air than in nitrogen, and they exhibited greater residue formation, which was not present in the TGA traces of many commercial polymers, including Nylons and PET. The residual mass fraction of H-PAAs in the air at $550{ }^{\circ} \mathrm{C}$ varied between 10 and $13 \%$. The residual mass fractions at $400{ }^{\circ} \mathrm{C}$ made it possible to identify the correlations between thermal stability and the number of carbon atoms in the bis-acrylamide moiety. The influence of the amino moiety structure was not uniquely identified, except in the case of the H-PAAs derived from piperazine, which were the most thermally stable considering both $\mathrm{T}_{\text {onset } 10 \%}$ and $\mathrm{T}_{\max }$.

Ignitability tests proved that resistance to direct flame impingement was excellent in all cases. The samples melted but did not burn and partially decomposed on the surface, turning yellow. The interior remained apparently intact.

H-PAAs were completely insoluble in water. However, the films of half of them became brittle when in contact with water. The H-PAAs most resistant to contact with water were B12-DM6 and B8-DM6. Subsequently, they were synthesized in bulk and characterized by wettability and tensile tests. They showed a similar Young's modulus (260 for B8-DM6 and $267 \mathrm{MPa}$ for B12-DM6), while the maximum stress, stress at break and strain at break increased from B8-DM6 to B12-DM6, apparently depending on the number of methylene groups in the bis-acrylamide moieties.

Supplementary Materials: The following are available online at https:/ / www.mdpi.com/2073-4 360/13/7/1018/s1, Figures S1-S3: ${ }^{1}$ H-NMR spectra of bis-acrylamides with assignments. Figures S4-S16: ${ }^{1} \mathrm{H}-\mathrm{NMR}$ spectra of H-PAAs with assignments. Figures S17-S29: FT-IR/ATR spectra of H-PAAs with assignments. Figure S30: TGA curves of B12-DM6 derived from solution and bulk synthesis in nitrogen (a) and air (b). Figures S31-S44: DSC thermograms of H-PAAs.

Author Contributions: Conceptualization, P.F. and A.M.; methodology, all the Authors contributed equally; formal analysis, A.M. and J.A.; investigation, M.M. (Massimo Marcioni), A.M., M.M. (Mario Malinconico) and P.L.; data curation, M.M.; writing-original draft preparation, A.M., E.R. and P.F.; writing-review and editing, A.M. and J.A.; supervision, A.M., E.R. and P.F. All authors have read and agreed to the published version of the manuscript.

Funding: The research was funded by Università degli Studi di Milano, Piano di sostegno alla ricerca 2018-2019, Linea 2 PSR2018_DIP_005.

Institutional Review Board Statement: Not applicable.

Informed Consent Statement: Not applicable.

Data Availability Statement: Not applicable.

Acknowledgments: The authors thanks Salvatore Mallardo (IPCB) for the technical assistance.

Conflicts of Interest: The authors declare no conflict of interest.

\section{References}

1. Ferruti, P. Polyamidoamines: Past, Present and Perspectives. J. Polym. Sci. Polym. Chem. 2013, 51, 2319-2353. [CrossRef]

2. Ranucci, E.; Manfredi, A. Polyamidoamines: Versatile bioactive polymers with potential for biotechnological applications. Chem. Afr. 2019, 2, 167-193. [CrossRef]

3. Mather, B.D.; Visvanathan, K.; Millerb, K.M.; Long, T.E. Michael addition reactions in macromolecular design for emerging technologies. Prog. Polym. Sci. 2006, 31, 487-531. [CrossRef]

4. Ferruti, P.; Marchisio, M.A.; Duncan, R. Poly(amido-amine)s: Biomedical Applications. Macromol. Rapid Commun. 2002, 23, 332-355. [CrossRef]

5. Ferruti, P.; Ranucci, E.; Bignotti, F.; Sartore, L.; Bianciardi, P.; Marchisio, M.A. Degradation Behaviour of Ionic Stepwise Polyaddition Polymers of Medical Interest. J. Biomater. Sci. Polym. Ed. 1995, 6, 833-844. [CrossRef] 
6. Arioli, M.; Manfredi, A.; Alongi, J.; Ferruti, P.; Ranucci, E. Highlight on the Mechanism of Linear Polyamidoamine Degradation in Water. Polymers 2020, 12, 1376. [CrossRef] [PubMed]

7. Barbucci, R.; Casolaro, M.; Nocentini, M.; Corezzi, S.; Ferruti, P.; Barone, V. Acid-Base and Metal Ion Complex Formation Properties of Polymers Containing Amino Acid Residues. Macromolecules 1986, 19, 37-42. [CrossRef]

8. Sartore, L.; Penco, M.; Della Sciucca, S.; Borsarini, G.; Ferrari, V. New carbon black composite vapor detectors based on multifunctional polymers. Sensors Actuat. B Chem. 2005, 111, 160-165. [CrossRef]

9. Sartore, L.; Barbaglio, M.; Borgese, L.; Bontempi, E. Polymer-grafted QCM chemical sensor and application to heavy metal ions real time detection. Sensors Actuat. B Chem. 2011, 155, 538-544. [CrossRef]

10. Sartore, L.; Barbaglio, M.; Penco, M.; Bergese, R.; Bontempi, E.; Colombi, P.; Depero, L.E. Polymer-coated quartz crystal microbalance chemical sensor for heavy cations in water. J. Nanosci. Nanotechnol. 2009, 9, 1164-1168. [CrossRef] [PubMed]

11. Barbucci, R.; Magnani, A. Physiochemical characterization and coating of polyurethane with a new heparin-adsorbing material. Biomaterials 1989, 10, 429-432. [CrossRef]

12. Barbucci, R.; Casolaro, M.; Magnani, A.; Roncolini, C. FTi.r. and potentiometric study of basic polymer behaviour in the free form, in different bulks, in both solid state and aqueous solution. Polymer 1991, 32, 897-903. [CrossRef]

13. Barbucci, R.; Albanese, A.; Magnani, A.; Tempesti, F. Coating of commercially available materials with a new heparinizable material. J. Biomed. Mater. Res. 1991, 25, 1259-1274. [CrossRef]

14. Caldwell, G.; Neuse, E.; Stephanou, A. Synthesis of water-soluble polyamidoamines for biomedical applications. II. Polymers possessing intrachain-type secondary amino groups suitable for side-chain attachment. J. Appl. Polym. Sci. 1993, 50, 393-401. [CrossRef]

15. Caldwell, G.; Neuse, E.W.; van Rensburg, C.E.J. Cytotoxicity of Selected Water-Soluble Polymer-cis-Diaminedichloroplatinum (II) Conjugates Against the Human HeLa Cancer Cell Line. J. Inorg. Organomet. Polym. 1997, P7, 217-231. [CrossRef]

16. Bencini, M.; Ranucci, E.; Ferruti, P.; Trotta, F.; Donalisio, M.; Cornaglia, M.; Lembo, D.; Cavalli, R. Preparation and in vitro evaluation of the antiviral activity of the Acyclovir complex of a $\beta$-cyclodextrin/poly(amidoamine) copolymer. J. Control. Release 2008, 126, 17-25. [CrossRef] [PubMed]

17. Mauro, N.; Ferruti, P.; Ranucci, E.; Manfredi, A.; Berzi, A.; Clerici, M.; Cagno, V.; Lembo, D.; Palmioli, A.; Sattin, S. Linear biocompatible glyco-polyamidoamines as dual action mode virus infection inhibitors with potential as broad-spectrum microbicides for sexually transmitted diseases. Sci. Rep. 2016, 6, 33393. [CrossRef]

18. Donalisio, M.; Quaranta, P.; Chiuppesi, F.; Pistello, M.; Cagno, V.; Cavalli, R.; Volante, M.; Bugatti, A.; Rusnati, M.; Ranucci, E.; et al. The AGMA1 poly(amidoamine) inhibits the infectivity of herpes simplex virus in cell lines, in human cervicovaginal histocultures, and in vaginally infected mice. Biomaterials 2016, 85, 40-53. [CrossRef] [PubMed]

19. Elzes, M.R.; Akeroyd, N.; Engbersen, J.F.J.; Paulusse, J.M.J. Disulfide-functional poly(amido amine)s with tunable degradability for gene delivery. J. Control. Release 2016, 244, 357-365. [CrossRef]

20. Lim, H.; Noh, J.; Kim, Y.; Kim, H.; Kim, J.; Khang, G.; Lee, D. Acid-Degradable Cationic Poly (ketal amidoamine) for Enhanced RNAInterference In Vitro and In Vivo. Biomacromolecules 2013, 14, 240-247. [CrossRef]

21. Cavalli, R.; Primo, L.; Sessa, R.; Chiaverina, G.; di Blasio, L.; Alongi, J.; Manfredi, A.; Ranucci, E.; Ferruti, P. The AGMA1 polyamidoamine mediates the efficient delivery of siRNA. J. Drug Target. 2017, 25, 891-898. [CrossRef] [PubMed]

22. Sun, Y.; Liu, H.; Xing, H.; Lang, L.; Cheng, L.; Yang, T.; Yang, L.; Ding, P. Bioreducible poly (amido amine) copolymers derived from histamine and agmatine for highly efficient gene delivery. Polym. Int. 2019, 68, 447-455. [CrossRef]

23. Ranucci, E.; Bignotti, F.; Paderno, P.L.; Ferruti, P. Modification of albumins by grafting poly (amido amine) chains. Polymer 1995, 36, 2989-2994. [CrossRef]

24. Magnaghi, V.; Conte, V.; Procacci, P.; Pivato, G.; Cortese, P.; Cavalli, E.; Pajardi, G.; Ranucci, E.; Fenili, F.; Manfredi, A.; et al. Biological performance of a novel biodegradable polyamidoamine hydrogel as guide for peripheral nerve regeneration. J. Biomed. Mater. Res. Part A 2011, 98 A, 19-30. [CrossRef]

25. Dos Reis, G.; Fenili, F.; Gianfelice, A.; Bongiorno, G.; Marchesi, D.; Scopelliti, P.E.; Borgonovo, A.; Podestà, A.; Indrieri, M.; Ranucci, E.; et al. Direct microfabrication of topographical and chemical cues for the guided growth of neural cell networks on polyamidoamine hydrogels. Macromol. Biosci. 2010, 10, 842-852. [CrossRef] [PubMed]

26. Martello, F.; Tocchio, A.; Tamplenizza, M.; Gerges, I.; Pistis, V.; Recenti, R.; Bortolin, M.; Del Fabbro, M.; Argentiere, S.; Milani, P.; et al. Poly (amido-amine)-based hydrogels with tailored mechanical properties and degradation rates for tissue engineering. Acta Biomater. 2014, 10, 1206-1215. [CrossRef] [PubMed]

27. Mauro, N.; Chiellini, F.; Bartoli, C.; Gazzarri, M.; Laus, M.; Antonioli, D.; Griffiths, P.; Manfredi, A.; Ranucci, E.; Ferruti, P. RGDmimic polyamidoamine-montmorillonite composites with tunable stiffness as scaffolds for bone tissue-engineering applications. J. Tissue Eng. Regen. Med. 2017, 11, 2164-2175. [CrossRef]

28. Gualandi, C.; Bloise, N.; Mauro, N.; Ferruti, P.; Manfredi, A.; Sampaolesi, M.; Liguori, A.; Laurita, R.; Gherardi, M.; Colombo, V.; et al. Poly-l-Lactic Acid Nanofiber-Polyamidoamine Hydrogel Composites: Preparation, Properties, and Preliminary Evaluation as Scaffolds for Human Pluripotent Stem Cell Culturing. Macromol. Biosci. 2016, 1533-1544. [CrossRef] [PubMed]

29. Manfredi, A.; Carosio, F.; Ferruti, P.; Ranucci, E.; Alongi, J. Linear polyamidoamines as novel biocompatible phosphorus-free surface-confined intumescent flame retardants for cotton fabrics. Polym. Degrad. Stabil. 2018, 151, 52-64. [CrossRef]

30. Schotten, C. Ueber die Oxydation des Piperidins. Ber. Dtsch. Chem. Ges. 1884, 17, 2544. [CrossRef] 
31. Baumann, E. Ueber eine einfache Methode der Darstellung von Benzoësäureäthern. Ber. Dtsch. Chem. Ges. 1886, 19, 3218. [CrossRef]

32. Vogel, A.I. Practical Organic Chemistry, 3rd ed.; Longman Group Ltd.: London, UK, 1957; pp. 582-584.

33. Fulmer, G.R.; Miller, A.J.M.; Sherden, N.H.; Gottlieb, H.E.; Nudelman, A.; Stoltz, B.M.; Bercaw, J.E.; Goldberg, K.I. NMR Chemical Shifts of Trace Impurities: Common Laboratory Solvents, Organics, and Gases in Deuterated Solvents Relevant to the Organometallic Chemist. Organometallics 2010, 29, 2176-2179. [CrossRef]

34. Babij, N.R.; McCusker, E.O.; Whiteker, G.T.; Canturk, B.; Choy, N.; Creemer, L.C.; De Amicis, C.V.; Hewlett, N.M.; Johnson, P.L.; Knobelsdorf, J.A.; et al. NMR Chemical Shifts of Trace Impurities: Industrially Preferred Solvents Used in Process and Green Chemistry. Org. Process. Res. Dev. 2016, 20, 661-667. [CrossRef]

35. Aboulkas, A.; El Harfi, K.; El Bouadili, A. Thermal degradation behaviors of polyethylene and polypropylene. Part I: Pyrolysis kinetics and mechanisms. Energy Convers. Manag. 2010, 51, 1363-1369. [CrossRef]

36. Bolbukh, Y.; Kuzema, P.; Tertykh, V.; Laguta, I. Thermal degradation of polyethylene containing antioxidant and hydrophilic/hydrophobic silica. J. Therm. Anal. Calorim. 2008, 94, 727-736. [CrossRef]

37. Matzen, M.; Kandola, B.; Huth, C.; Schartel, B. Influence of Flame Retardants on the Melt Dripping Behaviour of Thermoplastic Polymers. Materials 2015, 8, 5621-5646. [CrossRef] [PubMed]

38. Gorrasi, G.; Milone, C.; Piperopoulos, E.; Pantani, R. Preparation, processing and analysis of physical properties of calciumferriteCNTs/PET nano-composite. Compos. Part B 2015, 81, 44-52. [CrossRef]

39. Holland, B.J.; Hay, J.N. The thermal degradation of PET and analogous polyesters measured by thermal analysis-Fourier transform infrared spectroscopy. Polymer 2002, 43, 1835-1847. [CrossRef]

40. Zhao, M.; Yi, D.; Camino, G.; Frache, A.; Yang, R. Interdigitated crystalline MMT-MCA in polyamide 6. RSC Adv. 2017, 7, 861-869. [CrossRef]

41. Fina, A.; Camino, G. Ignition mechanisms in polymers and polymer nanocomposites. Polym. Adv. Technol. 2011, 22, 1147-1155. [CrossRef]

42. Manfredi, A.; Carosio, F.; Ferruti, P.; Alongi, J.; Ranucci, E. Disulfide-containing polyamidoamines with remarkable flame retardant activity for cotton fabrics. Polym. Degrad. Stab. 2018, 156, 1-13. [CrossRef]

43. Alongi, J.; Cuttica, F.; Di Blasio, A.; Carosio, F.; Malucelli, G. Intumescent features of nucleic acids and proteins. Termochim. Acta 2014, 591, 31-39. [CrossRef]

44. Costes, L.; Laoutid, F.; Brohez, S.; Dubois, P. Bio-based flame retardants: When nature meets fire protection. Mater. Sci. Eng. $R$ 2017, 117, 1-25. [CrossRef]

45. Salmeia, K.A.; Gaan, S.; Malucelli, G. Recent Advances for Flame Retardancy of Textiles Based on Phosphorus Chemistry. Polymers 2016, 8, 319. [CrossRef] [PubMed] 